\title{
Exploiting the Salience Bias in Designing Taxes
}

\author{
Deborah H. Schenk $\uparrow$
}

In making decisions, individuals rely on heuristics or cognitive biases. One of these is salience, which refers to visibility or prominence. Individuals are likely to focus on information or items that are prominent or salient and ignore those that are less visible. This Article develops an argument for exploiting this cognitive bias in designing or modifying taxes. Most commentary assumes that the intentional use of low-salience taxes by the government is undesirable and that increased salience is always required; to do otherwise is to take advantage of the cognitive bias that causes individuals to ignore taxes that are not prominent or salient. Although increasing salience is often desirable, there is a political-economy argument for intentionally exploiting this bias by incorporating low-salience provisions into tax design. By clarifying the concepts of transparency, complexity, and salience, this Article establishes a vocabulary that should facilitate more productive exchanges among behavioral economists, cognitive psychologists, and tax scholars regarding the salience of various revenue provisions. Moreover, and more importantly, this Article offers the first comprehensive case for the normative desirability of low-salience taxes. While others have suggested that low-salience taxes may enhance economic efficiency, scholars thus far have expressed skepticism about the desirability of low-salience taxation from a democratic-theory perspective. This Article shows why low-salience taxation may in fact be democracy-enhancing. The Article concludes with a case study where the use of low-salience tax provisions is justified and effective, that is, where Congress finds it necessary to minimize the prominence of the tax because politically it cannot increase marginal tax rates.

Introduction. 254

I. Disentangling Transparency, Complexity, and Salience ........................2256

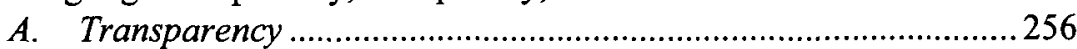

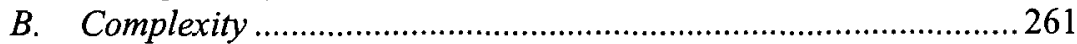

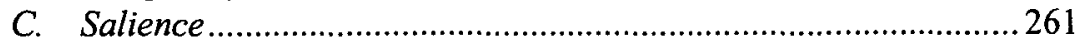

$\dagger \quad$ Marilynn and Ronald Grossman Professor of Taxation, New York University School of Law. I am grateful to the participants in the University of Pennsylvania Tax Policy Colloquium, the University of Michigan Tax Policy Colloquium, and the Loyola (LA) Law School Tax Policy Colloquium for their helpful comments and questions-particularly commentators Joseph Bankman, Michael Knoll, and Reed Shuldiner. Jay Cosel and Erika Siu provided excellent research assistance. My thanks to Chris Sanchirico, who first suggested to me that my support for the alternative minimum tax was tied to salience and sent me down this path. 
II. What We Know About Salience and Taxes ........................................... 264

A. Empirical Work.................................................................. 264

B. Why Do People Ignore (or Misperceive) Taxes?...................... 270

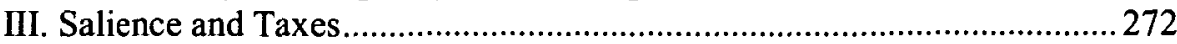

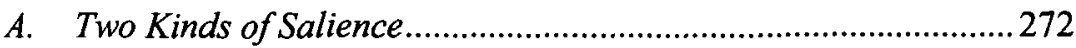

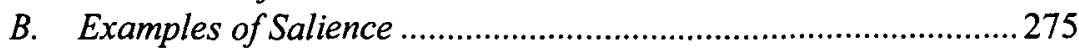

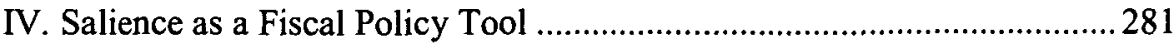

A. The Argument and Examples ................................................. 281

B. The Relationship Between Transparency, Complexity, and Salience .............................................................................. 285

V. Responding to Criticisms of Exploiting the Salience Bias.......................287

A. The Deliberate Use of Low-Salience Tax Provisions Is Undemocratic........................................................................28

B. Low-Salience Taxes Will Make It Easier for Legislators To Adopt Higher Taxes ............................................................ 290

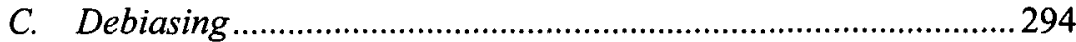

D. Distributional Concerns.........................................................295

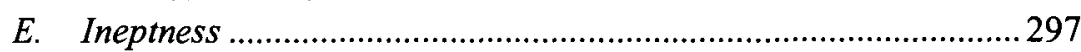

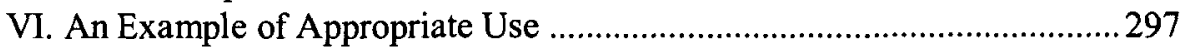

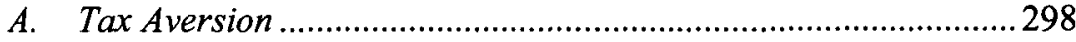

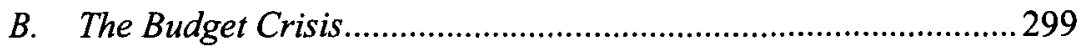

C. Political Rhetoric and the Impossibility of Raising Taxes Directly .............................................................................. 299

1. Interest Group Politics Predicts That Congress Will Not Support Raising Taxes Directly .........................................300

2. Institutional Barriers Predict That Congress Will Not Support Increasing Taxes Directly......................................303

3. Mitigating Factors That Might Result in Raising Taxes Directly Are Not Likely To Occur .......................................306

4. The Poisonous Atmosphere with Respect to Taxes Prevents Increasing Taxes Directly......................................308

D. The Use of Low-Salience Taxes as a Second-Best Solution ........ 310 Conclusion 310

Introduction

In making decisions, individuals rely on heuristics or cognitive biases. One of these is salience, which refers to visibility or prominence. Individuals systematically focus on items or information that is prominent or salient and ignore information or items that are less visible. This Article develops an argument for exploiting this cognitive bias in designing or changing taxes. 
Public finance and tax scholars recently have begun to consider the effects of low-salience taxes, with a focus on behavioral responses.' Some work has been done to untangle the cognitive biases that result in less attention being paid to low-salience taxes. Normative argument with respect to such taxes, however, is quite limited; there is almost a universal assumption that increased salience is preferred and that the intentional use of low-salience taxes by the government is undesirable. This distaste is manifested in the term often used to describe such taxes: "hidden taxes."

Much of the criticism of so-called hidden taxes is misdirected. It usually is lobbed in the guise of "transparency" and "complexity," terms that often are confused in the literature with "saliency." In developing the argument that salience may be an appropriate fiscal tool, it is useful to distinguish these concepts. Thus, this Article begins by setting out the differences among transparency, complexity, and salience. It establishes a vocabulary that should facilitate more productive exchanges among behavioral economists, cognitive psychologists, and tax scholars regarding the salience of various revenueraising provisions.

This Article differs significantly from past literature by rejecting the assumption that a low-salience tax is not desirable. It offers the first comprehensive case for the normative desirability of low-salience taxes. While others have suggested that low-salience taxes may enhance economic efficiency, scholars have thus far expressed skepticism about the desirability of low-salience taxation from a democratic-theory perspective. This Article shows why low-salience taxation may in fact be democracy-enhancing. It makes a political-economy argument that relying on salience is an acceptable fiscal tool. This Article considers criticisms that might be levied against the state for manipulating salience in adopting a tax provision. It concludes that none of these criticisms justifies a complete rejection of salience as a fiscal tool, but that they are a caution against extensively taking advantage of cognitive biases. Finally, this Article offers a case study where using low-salience provisions would be justified and effective. Under the current political landscape, in which there is a looming fiscal crisis but intense tax aversion and in which the politics of taxation make raising additional revenue extremely difficult, Congress would be well-advised to use low-salience provisions that make taxation more palatable.

1. This Article was accepted for publication before a preliminary draft of a paper on a similar subject by David Gamage and Darien Shanske became available. See David Gamage \& Darien Shanske, On Tax Salience: Market-Salience and Political-Salience (Sept. 12, 2010) (unpublished manuscript), available at http://taxprof.typepad.com/files/gamage-1.pdf. This Article thus does not discuss the analysis by Gamage and Shanske. The fact that several scholars are simultaneously exploring the normative implications of low-salience taxation underscores the importance of integrating behavioral economics into tax theory.

2. See, e.g., Brian Galle, Hidden Taxes, 87 WASH. U. L. REV. 59, 59 (2009); Edward A. Zelinsky, Unfunded Mandates, Hidden Taxation and the Tenth Amendment: On Public Choice, Public Interest, and Public Services, 46 VAND. L. REV. 1355, 1356 (1993). 
It is beyond question that when citizens contemplate taxes, there are cognitive biases at work. Salience is one of these biases. While we do not know all that we need to know about such biases, it is useful to begin to think about whether it is appropriate for legislators to exploit these biases. It is too early to develop a complete theory of whether this is appropriate, but we can begin to explore when it might be.

\section{Disentangling Transparency, Complexity, and Salience}

Public finance and tax literature frequently confuse the terms "transparency," "complexity," and "salience," often using them interchangeably. ${ }^{3}$ But these terms have different meanings and target different problems, and eliding these distinctions makes it difficult to understand the importance of these terms. The first step in the argument for the use of salience as a fiscal policy tool is to develop a taxonomy of terms that distinguishes them. This Part lays out a lexicon that should be helpful in developing the use of salience. This Article later returns to the interrelation of these concepts.

\section{A. Transparency}

The literature is replete with both arguments for transparency and complaints about the lack of transparency. These calls for transparency take several forms, but all share one trait: they say that transparency is desirable and a lack of transparency is bad. ${ }^{4}$ Calls for transparency in the tax system are common. ${ }^{5}$ Some commentators refer to transparency as requiring that

3. The ABA Tax Section, for example, "use[s] the term 'transparent' to describe tax laws that apply in a straightforward and predictable way." AM. BAR ASS'N SECTION OF TAXATION, STATEMENT OF POLICY FAVORING TAX SIMPLICITY, STABILITY, AND TRANSPARENCY 3, http:/www.americanbar.org/content/dam/aba/migrated/tax/pubpolicy/papers/whitepaper

sopfavoringtaxsimplicitystabilityandtransparency.authcheckdam.pdf (last visited Apr. 12, 2011). The Tax Section's "rough test of transparency is whether a taxpayer can easily estimate the tax effect of an increase in his or her income." Id. The Tax Section is talking about complexity, not transparency. Meanwhile, William Gales and Peter Orszag write that "the expansion of the AMT will raise complexity, and reduce efficiency, equity and transparency in the tax system." William G. Gales \& Peter R. Orszag, An Economic Assessment of Tax Policy in the Bush Administration, 2001-2004, 45 B.C. L. REV. 1157, 1165 (2004). Their reference to the "transparency" of the tax is directed at salience.

4. See, e.g., Francis FUKUYAMA, STATE-BUILDING: GoVERNANCE AND WORLD ORDER IN THE 21ST CENTURY 8-9 (2004) ("Strength [of institutions] includes . . a high level of transparency and accountability in government institutions ....."); Mark Fenster, The Opacity of Transparency, 91 IowA L. REV. $885,888(2006)$ (stating that transparency "is clearly among the pantheon of great political virtues"); Gia B. Lee, Persuasion. Transparency, and Government Speech, 56 HASTINGS L.J. 983, 98889 (2005) (elevating transparency to the level of a "principle" and arguing that the lack of transparency in government communications can have significant implications for public debate).

5. See, e.g., Robert Carroll et al., Moving Forward with Bipartisan Tax Policy 3 (Tax Found., Working Paper No. 5, 2009), available at http://www.taxfoundation.org/files/wp5.pdf ("We agree that the federal government should ... [c]reate a more transparent and straightforward tax code.”); Russell Roberts, A Radical Re-Imagining of The Tax System, Forbes.COM (Jan. 23, 2009, 3:55 PM), http://www,forbes.com/2009/01/23/taxes-obama-recovery-oped-cx_r_0123roberts.html (calling for a "more transparent tax system"). 
information held by the government be available to the public. ${ }^{6}$ Others complain about a lack of transparency when Congress adopts a tax provision without hearings or debate, or entertains the proposals of lobbyists behind closed doors. ${ }^{7}$ Still others complain that legislation is not transparent because it is difficult to understand, because the taxpayer cannot figure out the effects of a provision, ${ }^{8}$ or because it is impossible to determine from the face of the statute who benefits from the tax provisions or transition rules. ${ }^{9}$ Commentators also object to a lack of transparency when congressional rhetoric about taxes does not match the reality: for example, when legislators claim that the maximum marginal tax rate has not changed, but phase-outs and rate bubbles have raised the rate significantly for some taxpayers. ${ }^{10}$ Still others object to "hidden taxes" because they are not transparent-by which they mean that they are not visible or prominent. ${ }^{11}$ These complaints are not identical. They lump transparency with complexity and salience.

For purposes of this Article's argument, the term "transparency" is reserved for transparency in the political process. ${ }^{12}$ This substantially overlaps

6. See, e.g., Cheryl D. Block, Pathologies at the Intersection of the Budget and Tax Legislative Processes, 43 B.C. L. REV. 863, 903 (2002) ("[T]ransparency surely requires that information be available to the public....").

7. See, e.g., Darren Goode \& Robin Bravender, GOP Staff, Energy Lobby in Closed Door Talks, POLITICO (Jan. 20, 201 1, 4:32 AM), http://www.politico.com/news/stories/01 11/47867.html.

8. See, e.g., AM. BAR ASS'N SECTION OF TAXATION, supra note 3, at 4 ("The Section urges the Congress and the Administration to ... [a]void phaseouts, minimum tax rules, and similar measures that obscure the practical effect of tax law on economic activity.").

9. See, e.g., SusAn J. IRVING, U.S. Gen. ACCOUNTING OFFICE, GAO/T-AIMD-96-129, BUdGeT PROCESS: EVOLUTION AND CHALLENGES 14 (1996), available at www.gao.gov/archive/1996/ai96129t.pdf ("Transparency is important because the budget debate is critically important-not because of the numbers in it but because it represents a statement about collective priorities and collective action. In a democracy, the debate about these priorities should be made as understandable as possible."); Block, supra note 6, at 903 (stating that information about the budget process should be "offered in a simple format").

10. For example, when Congressman Don Pease pushed for passage of a provision limiting itemized deductions for high-income taxpayers, he asserted: "It raises the taxes of the wealthy without being a tax rate increase." Pease Circulates "Dear Colleague" Letter on Deduction Limits, TAX NOTES TODAY, Oct. 24, 1990, 90 TNT 217-10 (LEXIS).

11. Charles McLure, for example, asserts under the heading of transparency that "taxation should not be imposed in ways that obscure its burden." Charles E. McLure, Jr., Rethinking State and Local Reliance on the Retail Sales Tax: Should We Fix the Sales Tax or Discard It?, 2000 BYU L. REV. 77, 79; see also Stefano DellaVigna, Psychology and Economics: Evidence from the Field, $47 \mathrm{~J}$. ECON. LIT. 315,350 (2009) (referring to low-salience taxes as "nontransparent taxes"); Christopher C. Fennell \& Lee Anne Fennell, Fear and Greed in Tax Policy: A Qualitative Research Agenda, 13 WASH. U. J.L. \& POL'Y 75, 129-33 (2003) (exploring the possibility of "transparent taxpaying," by which the authors mean making both federal spending and the contributions of other taxpayers more visible, which might result in "improved political efficacy of the citizenry"); Elizabeth Garrett, Accountability and Restraint, The Federal Budget Process and the Line Item Veto Act, 20 CARDOZO L. REV. 871, 924 (1999) ("[T]ransparency is particularly important because individual decisions can be lost in the midst of detailed and obscurely worded omnibus bills. In the absence of visibility, accountability is virtually impossible."); Edward J. McCaffery \& Jonathan Baron, The Political Psychology of Redistribution, 52 UCLA L. REV. 1745, 1753 (2005) (contrasting "hidden" and "transparent" taxes).

12. For examples of the use of "transparency" in this way, see Block, supra note 6, at 869 ("In a democratic government, it is important for such decisions to be transparent and open and for legislators to be fully accountable."); and Julie Roin, Truth in Government: Beyond the Tax Expenditure 
with transparency in governance, although the latter term often is used in a much broader way than intended here. Transparency in governance is almost universally viewed as a political virtue, a distinguishing characteristic of democracy. In recent decades, it has emerged as a core aspect of governance. ${ }^{13}$ Despite its position as a principal political norm, however, there is no accepted definition of what transparency requires or from where it derives. Utilizing its dictionary meaning, almost every conception relies on "openness" in government in the sense of being open to view, particularly with respect to the sharing of information. Claims with respect to transparency fall into two classes. The first is that a transparent or open government is foundational in a liberal democracy. ${ }^{14}$ Under this view, the availability of laws and regulations, as well as the openness of actions of the government, is required in a democracy. ${ }^{15}$ Individuals must be informed in order for them to consent to be governed. Furthermore, citizens must have sufficient information to engage in a meaningful public debate about public institutions and government actions. ${ }^{16}$ Many of those who argue for "transparency" as a foundational matter are arguing not only for the government to disseminate information, but also to do so in a manner that makes the information available.

The second claim is instrumentalist. Transparency enables the public to monitor the government and to take actions against incompetency and corruption. Access to information improves criticism and review, enables better government oversight and regulation, promotes better functioning markets, and facilitates improved international relations. ${ }^{17}$ Lack of access to information about government benefits and government spending may cause voters to make poor political decisions about which officials to elect and which laws to

Budget, 54 HASTINGS L.J. 603 (2003) (arguing for the value of transparency with respect to tax expenditures).

13. Thomas Blanton, The World's Right To Know, ForEIGN POL'Y, July 2002, at 50.

14. The claim that transparency is foundational often rests on James Madison. See Letter from James Madison to W.T. Barry (Aug. 4, 1822), in THE COMPLETE MADISON: HIS BASIC WRITINGS 337 (Saul K. Padover ed., 1953) ("[A] people who mean to be their own Governors, must arm themselves with the power which knowledge gives."). For attributions to Jeremy Bentham and John Stuart Mill, see Joseph E. Stiglitz, Senior Vice President \& Chief Economist, The World Bank, Oxford Amnesty Lecture at the Univ. of Oxford: On Liberty, the Right To Know, and Public Discourse: The Role of Transparency in Public Life 6 (Jan. 27, 1999), available at http://derechoasaber.org.mx/documentos/pdf0116.pdf.

15. JOHN RAWLS, A THEORY OF JUSTICE 16, 454 (1971) (indicating that transparency is a necessary condition for a just society so that individuals are informed about their choices in being governed); Fenster, supra note 4, at 898 ("Openness is a necessary condition of popular democratic power, a predicate for effective representative government, and an indispensable part of the everyday life of the free individual and of the wider demos.").

16. See, e.g., AMY GUTTMAN \& DENNIS THOMPSON, DEMOCRACY AND DiSAGREEMENT 10001 (1996); JAMES G. MARCH \& JOHAN P. OLSEN, DEMOCRATIC GOVERNANCE 146-48 (1995); see also Fenster, supra note 4, at 897 ("In short, liberal democratic theory requires the state to give an account of itself to its public and to justify its actions to the individual and community."); Stiglitz, supra note 14, at 7 (arguing that the most compelling justification for openness is that "meaningful participation in democratic processes requires informed participants").

17. See Fenster, supra note 4, at 899-902 (cataloguing the consequentialist claims for transparency); Stiglitz, supra note 14 , at 27. 
support. Another consequentialist claim is economic: in general, access to information should promote better resource allocation and efficiency. Hidden information may enable those who have the information to extract rents.

But even advocates of transparency agree that absolute transparency is neither desirable nor necessary. For logistical and financial reasons, the government could not function if every meeting involving government personnel or every document passing through a government agency had to be provided to all citizens. ${ }^{18}$ Significant privacy concerns arise in requiring the government to release private information that must be disclosed to the government. There are also concerns over security breaches, the quality of government decisionmaking, and the effects on competition in the marketplace. ${ }^{19}$ Thus, for example, Congress does not open its doors to all committee meetings; ${ }^{20}$ defense and security matters are exempted from the Freedom of Information Act; ${ }^{21}$ and tax return information cannot be disclosed. ${ }^{22}$

How transparency as a core principle is to be carried out is more ambiguous. The general idea is that the government should operate in the open and not in secret and should strive to make information available to the public. Joseph Stiglitz described this type of transparency as "a basic right to know, to be informed about what the government is doing and why."23 Some aspects of transparency are so ingrained as to not need legislation. For example, congressional sessions are scheduled and open to the public, hearings are public, and legislation is printed and widely distributed. Other aspects of open

18. Fenster, supra note 4, at 902 ("Government cannot operate in a manner that provides complete access to all proceedings and documents. Complete transparency not only would create prohibitive logistical problems and expenditures . . . but more importantly, it would impede many of the government's most important operations ....").

19. See id at 906-10 (cataloguing limitations on transparency); Stiglitz, supra note 14, at 18 25. There are also those who argue that the benefits from transparency are minimal, see, for example, Neal D. Finkelstein, Introduction: Transparency in Public Policy, in TRANSPARENCY IN PUBliC POLICY: GREAT BRITAIN AND THE UNITED STATES 1, 1 (Neal D. Finkelstein ed., 2000); that transparency may cause constitutional harms, see, for example, Antonin Scalia, The Freedom of Information Act Has No Clothes, REgulation, Mar./Apr. 1982, at 14; and that there are negative, perhaps unintended consequences, such as security breaches, greater access to information by criminals, increased fiscal costs, loss of privacy, and an inability to govern because of sunshine, see, for example, Fenster, supra note 4, at 907-08, 936-38; James T. O'Reilly, FOIA and Fighting Terror: The Elusive Nexus Between Public Access and Terrorist Attack, 64 LA. L. REV. 809, 812-14 (2004); and Laura A. White, The Need for Governmental Secrecy: Why the U.S. Government Must Be Able To Withhold Information in the Interest of National Security, 43 VA. J. INT'L L. 1071 (2003).

20. See STANDING RULES OF THE SENATE, S. Doc. No. 110-9, R. XXVI, at 33 (2007), available at http://www.gpoaccess.gov/serialset/cdocuments/featured/senate.html (follow links for text or PDF of "S. Doc. 110-9") (allowing committee meetings to be closed to the public for enumerated reasons, including "the interest of national defense or the confidential conduct of the foreign relations of the United States").

21. 5 U.S.C. $\$ 552$ (b) (2006) (exempting certain information from Freedom of Information Act requirements "in the interest of national defense or foreign policy").

22. I.R.C. $\$ 7216$ (2006) (prohibiting disclosure of tax-return information by tax-return preparers).

23. Stiglitz, supra note 14 , at 1 . 
government have been legislated to require the government to act in the open and to make information available. For example, the Government in the Sunshine Act requires federal agencies to open certain meetings to the public. ${ }^{24}$ Also, the Freedom of Information Act requires the government to release certain information to the public. ${ }^{25}$ Although the key component is that information should be available to voters, it is well accepted that the information must be accessible, complete, relevant, and reliable. ${ }^{26}$

In the tax arena, transparency is widely perceived to be a desirable trait of government, but what that means is somewhat clouded. Some of what is required is already in place, but other manifestations of transparency are limited or ineffective. Legislation and regulations are publicly available. ${ }^{27}$ Citizens, however, must have the opportunity to provide input on legislation and regulation. The Administrative Procedure Act and internal rules generally provide the opportunity for anyone to comment on regulations, ${ }^{28}$ but it is much more difficult to comment on other administratively issued rulings. In addition, while Congress often holds hearings with respect to legislation, there are two significant problems. The first is that while almost all hearings are open to the public, it is generally not possible for citizens to regularly provide input. Second, the legislation that ultimately is adopted is not necessarily the legislation on which the hearings were held. Committee deliberations and mark-ups are closed to the public, so it is often difficult for citizens to understand Congress's intention. There is also a significant lack of transparency in the extent to which special interests control the legislative process. Cloaking the process in darkness hides the extent to which legislation provides special benefits, such as tailored transition rules. A lack of information will cause voters to make poor decisions about government spending and revenue raising.

24. Pub. L. No. 94-409, 90 Stat. 1241 (1976) (codified at 5 U.S.C. $\S 552(b)$ ).

25. Pub. L. No. $89-487,80$ Stat. 250 (1966) (codified at 5 U.S.C. $\S 1002$ ).

26. See, e.g., Tara Vishwanath \& Daniel Kaufmann, Towards Transparency in Finance and Governance (Sept. 6, 1999) (unpublished manuscript), available at http://ssm.com/abstract=258978. Another manifestation that sometimes appears in the literature with respect to the rule of law is the requirement that legislation not only be accessible but also comprehensible. This, however, concerns complexity and is discussed in the next Section.

27. See GPO ACCESS, http://www.gpoaccess.gov (last visited Feb. 21, 2011) (providing free online access to official information, including laws, regulations, and U.S. Supreme Court opinions).

28. See, e.g., 5 U.S.C. $\S 553$ (c) ("After notice required by this section, the agency shall give interested persons an opportunity to participate in the rule making through submission of written data, views, or arguments with or without opportunity for oral presentation."). 


\section{B. Complexity}

Commentary decrying the complexity of the tax system is legion. ${ }^{29}$ Like transparency, complexity has many meanings, which often overlap with both transparency and salience. ${ }^{30}$

For ease of explication, this Article limits complexity to refer to a taxpayer's ability to understand and comply with a statutory provision or regulation. As David Bradford noted, however, even that use of the term connotes differing problems. The first is compliance complexity, which refers to the difficulties that taxpayers face in recordkeeping, making calculations, filing the return, and complying with the regulations imposed by the Internal Revenue Service. The second is transactional complexity, which refers to the costs taxpayers face in changing their behavior to minimize their tax liabilities. The third type of complexity is rule complexity, which refers to the difficulty in understanding and interpreting legislative and regulatory rules. ${ }^{31}$

Overlap arises because, like salience, the complexity of tax provisions can affect or change taxpayer behavior. Transactional complexity itself encapsulates that aspect because it references behavioral changes that occur because of the tax rules. And although complexity can obscure salience, the former term should be used to refer to the difficulty in understanding a rule as opposed to how prominent it is.

Complexity can also refer to process; thus, it would not be incorrect to note that the process of enacting tax legislation is quite complex. But to clarify the argument, this Article limits its definition of transparency to the legislative process, and its definition of complexity to understanding and complying with legislation and regulations.

\section{Salience}

Salience is often confused with both transparency and complexity, but this Article will distinguish it for purposes of its argument. Salience has relevance in a number of academic disciplines, and although the meaning is not completely consistent, it is usually a variation of the dictionary definition of "standing out conspicuously" or "prominent.",32 Political scientists, for

29. See, e.g., Walter Alarkon \& Jay Heflin, Few Lawmakers File Their Own Tax Returns, Citing Code's Complexity, THE HLL (Apr. 14, 2010, 7:32 PM), http://hehill.com/homenews/house/92377-few-members-file-own-returns.

30. See, e.g., Bob Williams, The Benefits of Opacity, TAxVox (May 28, 2009, 4:00 PM), http://taxvox.taxpolicycenter.org/blog/_archives/2009/5/28/4202956.html (noting overlap between tax complexity and "tax awareness"); see also Carroll et al., supra note 5, at 5 (contrasting the "complexity and opaqueness of our current tax code" with a proposed system that would be "more transparent and simpler").

31. DAVID F. BRADFORD, UNTANGLING THE INCOME TAX 266-67 (1986).

32. Salient, MERRIAM-WEBSTER.COM, http://www.merriam-webster.com/dictionary/salient (last visited Feb. 21, 2011). 
example, utilize "salience" to describe the issues that voters care about, ${ }^{33}$ and various theories modeling political manipulation argue that politicians engage in changing the relative salience of issues confronting voters. ${ }^{34}$ Psychologists and sociologists use the concept to demonstrate that the prominence of something may affect an individual's behavior. ${ }^{35}$ Behavioral economists refer to salience as a bias in favor of prominent or visible information that affects people's economic behavior and responses. ${ }^{36}$

It is this sense of prominence or visibility that this Article attaches to the term salience. ${ }^{37}$ With respect to taxation, salience is used to describe the degree to which a tax or a tax provision is visible or prominent to the public. Many commentators refer to low-salience taxes as "hidden taxes."38 But "hidden tax"

33. Macartan Humphreys \& John Garry, Thinking About Salience 2 (Mar. 2000) (unpublished manuscript), available at http://www.columbia.edu/ mh2245/papers1/salience.pdf.

34. See, e.g., Willer RIKER, THE ART OF POLTTICAL MANIPUlation 151 (1986).

35. See, e.g., Shelley E. Taylor, The Availability Bias in Social Perception and Interaction, in JUDGMENT UNDER UNCERTAINTY: HEUR ISTICS AND BIASES 190, 192 (Daniel Kahneman, Paul Slovic \& Amos Twersky eds., 1982) ("Salience biases refer to the fact that colorful, dynamic, or other distinctive stimuli disproportionately engage attention and accordingly disproportionately affect judgments."); Leslie K. John, Alessandro Acquisti \& George Loewenstein, The Best of Strangers: Context-Dependent Willingness To Divulge Personal Information 5 (July 6, 2009) (unpublished manuscript), available at http://ssm.com/abstract=1430482 (showing that the salience of concerns about privacy motives causes subjects to be less willing to admit to sensitive behaviors).

36. For salience effects not relating to public finance, see, for example, Tanjim Hossain \& John Morgan, Plus Shipping and Handling: Revenue (Non) Equivalence in Field Experiments on eBay, 62 ADVANCES ECON. ANALYSIS \& POL'Y, no. 2, 2006, at 4, available at http://www.bepress.com/bejeap/advances/vol6/iss2/art3.

37. Another noted characteristic of something that is salient is that it is easy to process. Edward J. McCaffery \& Jonathan Baron, Isolation Effects and the Neglect of Indirect Effects of Fiscal Policies, 19 J. BEHAV. DECISION MAKING 289, 289 (2006).

38. See, e.g., Jennifer Arlen \& Deborah M. Weiss, A Political Theory of Corporate Taxation, 105 YALE L.J. 325, 332 (1995); Maureen B. Cavanaugh, On the Road to Incoherence: Congress, Economics, and Taxes, 49 UCLA L. REV. 685, 697 (2001); Galle, supra note 2, at 59; McCaffery \& Baron, supra note 37, at 289; Nancy C. Staudt, Taxation Without Representation, 55 TAX L. REV. 555, 589-90 (2002); C. Eugene Steuerle \& Martin A. Sullivan, Toward More Simple and Effective Giving: Reforming the Tax Rules for Charitable Contributions and Charitable Organizations, 12 AM. J. TAX POL'Y 399, 446 (1995) (referring to "hidden tax rates"); Zelinsky, supra note 2, at 1356; William Congdon, Jeffrey R. Kling \& Sendhil Mullainathan, Behavioral Economics and Tax Policy 8 (Nat'l Bureau of Econ. Research, Working Paper No. 15328, 2009), available at http://www.nber.org/papers/w15328; Arno Riedl, Behavioral and Experimental Economics Can Inform Public Policy: Some Thoughts 15-16 (Ctr. for Econ. Studies \& Ifo Inst. for Econ. Research, Working Paper No. 2902, 2009), available at http://ssrn.com/abstract=1536428; Jacob Nussim, Taxes, Prices, and Consumer Protection 40 (Jan. 20, 2009) (unpublished manuscript), available at http://ssm.com/abstract=1397643; see also George Loewenstein, Deborah A. Small \& Jeff Stmad, Statistical, Identifiable and Iconic Victims, in BEHAVIORAL PUBLIC FNANCE 39 (Edward J. McCaffery \& Joel Slemrod eds., 2006) (describing a hidden tax "in its pure form" as "one where all of the possible ultimate payors believe that the tax is being paid by someone else"); J.D. Foster, Lifting the Lid on Hidden Taxes, TAX FouND., Apr. 15, 2000, http:/www.taxfoundation.org/commentary/show/184.html; Brian Wingfield, Washington's Hidden Taxes, FORBES.COM (July 25, 2007, 6:00 AM), http://www.forbes.com/2007/07/24/washington-taxes-congress-biz-beltway-cx-bw _

0725hiddentaxes.html. Edward McCaffery and Jonathan Baron use the term "hidden taxes" in two ways. They describe "partially hidden taxes" as those where the tax is built into the price-such as a VAT or excise tax-and where the amount of the tax is known. In their terminology, "fully hidden taxes" are those where the incidence of the tax is not known, such as corporate or business taxes. McCaffery \& Baron, supra note 37 , at 289 
is a misnomer. ${ }^{39}$ The taxes that are commonly labeled as hidden-such as a value-added tax ("VAT") or a noninclusive sales tax-are not actually "hidden" in the commonsense meaning of the word. Information about the tax-most importantly, the rate and the commodities on which it is imposedis readily available to the public. ${ }^{40}$ This is true with respect to specific tax provisions as well. It is hard to think of any tax provision that is hidden in the sense of being unknown or about which information is unavailable. ${ }^{41}$ In every case, the information about the tax-the rates, how it is imposed, and how it is collected-is obtainable. The taxes are "hiding" in plain sight. Thus, salience refers to prominence, not accessibility. It is useful to think of salience in terms of behavioral effects. A tax burden motivates behavioral change. A salient tax (or tax provision) is predicted to affect taxpayer behavior; conversely, a lowsalience tax (or provision) predictably would change behavior less or not at all. If taxpayers are unaware of the tax or provision, then they cannot respond to it; if the tax or provision is not prominent, they will underreact. Thus, salience is relevant even where the tax or provision is known.

With respect to taxes, salience and complexity overlap in several ways, but they are not identical. If a tax is difficult to understand, compute or process (that is, if it is complex), it is likely to be less salient. The rule complexity of many income tax provisions causes them to lose their salience. ${ }^{42}$ More complex taxes create more opportunities for salience to be an issue.

But very simple provisions may not be salient either. Most retail sales taxes, for example, are relatively simple-a flat percentage of the purchase price of a commodity - but depending on the way in which they are presented, they may have low salience. Conversely, some highly complex provisions may attain great prominence in the political debate. The earned income tax credit ("EITC") has very complex definitional rules and requires complex calculations, but its existence, as well as the possibility of receiving of large checks, has high salience.

39. Another misnomer is the term "stealth tax," which is sometimes used as an alternative to "hidden tax." See, e.g., AM. BAR ASS'N SECTION OF TAXATION, supra note 3, at 1, 3.

40. See Susanne Lohman \& Deborah M. Weiss, Hidden Taxes and Representative Government: The Political Economy of the Ramsey Rule, 30 PUB. FIN. REV. 579, 584 (2002) ("After all, tax rate information is 'public information' in the sense that the public has access to government publications listing tax rates on all sorts of economic activities in exhaustive detail."); Edward $\mathrm{J}$. McCaffery, Cognitive Theory and Tax, 41 UCLA L. REV. 1861, 1873 (1994) ("[A] 'hidden' tax can actually be quite certain and knowable.").

41. Contrast this with a tax rule providing that taxpayers draw a slip of paper out of a black box to ascertain their marginal tax rate. There, the process of determining the rate and the information about the rates themselves would actually be hidden.

42. See, e.g., Lawrence J. Kotlikoff \& David Rapson, Does It Pay, at the Margin, To Work and Save?-Measuring Effective Marginal Taxes on Americans' Labor Supply and Saving 1, 25-28, 36 (Nat'l Bureau of Econ. Research, Working Paper No. 12533, 2006), available at http://www.nber.org/papers/w12533 ("[T]hanks to the incredible complexity of the U.S. fiscal system, it's impossible for anyone to understand her incentive to work, save, or contribute to retirement accounts absent highly advanced computer technology and software."). 


\section{What We Know About Salience and Taxes}

Although the argument this Article makes is a political one, most of what we know about salience comes from work that looks at the effect of the salience of particular taxes on economic decisionmaking. It is that work that allows us to speculate on the effect of salience on political decisions with respect to taxes.

\section{A. Empirical Work}

The argument that salience is relevant to taxes derives from behavioral economics. In this branch of economics, economists apply the concepts of cognitive psychology, specifically certain biases, to economic decisionmaking. They argue that individuals operate with bounded rationality; that is, individuals often systematically deviate from what would be expected from a rational, self-interested person in making economic decisions. ${ }^{43}$ Therefore, the standard assumptions made in the prevailing model of decisionmaking do not hold. ${ }^{44}$ The relevance of salience is usually traced to Amos Tversky and Daniel Kahneman, who laid out several heuristics that bias decisionmaking. ${ }^{45}$ The relevant one here is "availability." In making a decision, individuals are often biased in that they rely too heavily on information that is readily available or prominent, ignoring information that they do not see as often or as readily or that is in the background. Tversky and Kahneman noted that "availability is affected by factors other than frequency and probability ... such as salience.",46 Thus, the salience (prominence) of an object or idea is one factor that may cause the use of an availability heuristic to affect behavior. Other economists studied the extent to which these biases and heuristics, including salience,

43. The standard rational-actor model posits that "all human behavior can be viewed as involving participants who maximize their utility from a stable set of preferences and accumulate an optimal amount of information and other inputs in a variety of markets." GARY S. BECKER, THE ECONOMIC APPROACH TO HUMAN BEHAVIOR 14 (1976).

44. Early applications were modifications of the standard rational-actor model that led to the idea that individuals have bounded rationality. See, e.g., HERBERT SIMON, REASON IN HUMAN AfFa IRS 19-23 (1983). Of course, modern behavioral economics does more than point out that assumptions in standard economic models do not hold in actuality. Behavioral economists generally argue that these assumptions are consistently violated and therefore are not useful as assumptions for modeling. As a result, the modeling itself is invalid.

Behavioral economics is not universally accepted. Many mainstream economists reject it entirely. For a review of the stand-off and a discussion of the sources of skepticism, see B. Douglas Bernheim, On the Potential of Neuroeconomics: A Critical (But Hopeful) Appraisal, 1 AM. ECON. J. MiCROECONOMICS 1 (2009). For the purposes of its argument, this Article does not need to take a position in the debate over the validity of the standard model of decisionmaking. Insights about cognitive biases are relevant for tax-policy design regardless of whether they upend standard economic models.

45. Amos Tversky \& Daniel Kahneman, Judgment Under Uncertainty: Heuristics and Biases, $185 \mathrm{SCl} .1124$ (1974).

46. $\quad I d$. at 1127 . 
affected economic decisionmaking. ${ }^{47}$ They tested whether individuals actually used various heuristics to make decisions. Generally, they demonstrated that when something was more salient (more prominent or visible), it had a more pronounced effect on behavior and responses.

In the last decade, researchers have begun to consider whether cognitive biases apply to decisionmaking with respect to taxes. ${ }^{48}$ Some empirical work and modeling has been done to explore whether the salience of a tax affects economic behavior and the ways in which it might do so. Understanding this literature can illuminate how Congress might use salience as a fiscal tool.

In a widely cited empirical study, Raj Chetty, Adam Looney, and Kory Kroft focused on the extent to which salience affected a consumer's perception of price and how that affected demand for a consumption product. They concluded that "individuals know about taxes when their attention is drawn to the subject, but do not pay attention to taxes that are not transparent when deciding what to buy." 49 The study established that although most consumers knew the rate of the applicable sales tax in the location where they were shopping, their behavior was more sensitive to after-tax prices when the amount of sales tax was posted (in other words, quite visible). The experiment was conducted in a supermarket where posted prices generally were exclusive of sales tax (that is, the tax was added at the register so that a consumer needed to know the amount of the tax and do a calculation in order to decide whether to purchase based on the total price). To test whether consumers underreacted to the tax-exclusive sales price, the authors also posted price tags displaying the tax-inclusive price. The study showed that posting the tax-inclusive price reduced demand by close to the amount of the sales tax, and from this they inferred that most consumers usually did not take the tax into account in making consumption decisions. Thus, the more salient tax-inclusive price changed consumer behavior more than the less visible tax-exclusive price. ${ }^{50} \mathrm{To}$ offset the possibility that some behavioral change could be due to a short-run violation of norms, the authors also studied the long-term effects of taxes on alcohol consumption. Alcohol is subject to an excise tax included in the retail price and a sales tax added on purchase. Looking at state-level changes in these

47. For an early application of the cognitive-psychology concept of salience to economic theory, see George A. Akerlof, Procrastination and Obedience, 81 AM. ECON. REv. 1 (1991). Akerlof argued that individuals systematically failed to maximize their utility. He applied what he described as "a central principle of modern cognitive psychology" under which individuals attach too much weight to salient events. Id. at 2.

48. The earliest work was done by Edward McCaffery and subsequently with Jonathan Baron. See McCaffery, supra note 40; McCaffery \& Baron, supra note 11.

49. Raj Chetty, Adam Looney \& Kory Kroft, Salience and Taxation: Theory and Evidence, 99 AM. ECON. REV. 1145, 1165 (2009). Although the authors used the term "transparent," it is clear from the study that they were focusing on salience.

50. Chetty and his coauthors focused on prices rather than tax rates because they were interested in behavioral responses to prices rather than to rates. As they noted, the tax rate may actually be less visible in a tax-inclusive price, but the total price is more visible. Id. at $1146 \mathrm{n} .2$. This is a good illustration of the difference between economic salience and political salience discussed below. 
two taxes along with annual data on beer consumption by state, they found that increases in the excise tax reduced beer consumption by an order of magnitude more than a similar increase in the sales tax. ${ }^{51}$ Again, they concluded that the less salient tax changed behavior less.

In another empirical study, Amy Finkelstein explored the sensitivity of drivers to the salience of tolls collected electronically. ${ }^{52}$ The study examined the impact of the adoption of electronic toll collection on toll rates. Her work is useful on several fronts. Her survey data indicated that drivers who used EZ Pass did not know either the rate at which the toll was imposed or their periodic costs. EZ Pass is a very low-salience way of collecting tolls because unlike drivers who hand over cash to a toll collector, a driver using EZ Pass has the toll collected automatically while passing the toll booth. ${ }^{53}$ Although information about the amount of the toll was readily available, ${ }^{54}$ drivers either ignored the amount of the toll or were unaware of it. Finkelstein's work produced evidence that the salience of the tax affected commuters' elasticity of demand.

These studies confirm the intuition that unless the amount of the tax is prominent, consumers will make consumption decisions "pretax," even though they are aware that a tax will be imposed and even where calculation of the tax is relatively uncomplicated. One could imagine other economic decisions where this is likely to be true. ${ }^{55}$

There is also some limited work on the effect of salience on the politics of taxation. Finkelstein's study also tested the oft-stated concern that low-salience taxes make it easier for legislators to raise tax rates. ${ }^{56}$ She found robust evidence that toll rates increased after the adoption of electronic collection. ${ }^{57}$ The implication is that legislators were less concerned with political backlash from toll increases when the method of collection was of low salience.

51. Id. at 1146 .

52. Amy Finkelstein, EZ-Tax: Tax Salience and Tax Rates, 124 Q.J. ECON. 969 (2009).

53. Surely a significant explanation for the lack of salience is the way the funds for tolls on EZ Pass systems are collected. To use the system, the driver must create an EZ Pass account by purchasing via credit card a flat amount (such as $\$ 25$ ), which is used to pay the tolls that the user incurs. Additional amounts are reloaded automatically via credit card.

54. In many locations, the amount of the toll is posted or flashes on a monitor before it is paid. Alternatively, the driver could examine the EZ Pass statement sent to all users. Thus, it cannot be said that the information is hidden; it is of low salience.

55. For example, when deciding which entrée to order at a restaurant, a consumer who takes cost into account is likely to choose based on the price for the entrée listed in the menu even though the actual price will include tax and tip. Conversely, where the price of the commodity or service is taxinclusive-as with parking-garage fees that include local taxes or gasoline prices that include excise taxes-decisions are likely to be based on the total cost. Online airline and rental-car bookings might be ripe for study, to compare those cases where the listed fee does not include all taxes with those cases where it does.

56. See infra Section V.B.

57. Finkelstein, supra note 52, at 1008-09. 
A study by Marika Cabral and Caroline Hoxby that focused on the politics of property taxes found that property tax rates were higher in areas where property taxes were less salient. One key way in which property taxes were less salient was the common method of paying the taxes by tax escrow-the property tax is paid by the holder of the mortgage and is lumped together with all payments made to the bank. The study also found that when a state's tax escrow rises, voters support fewer statewide referenda that limit property taxes. Conversely, when property taxes are more salient, they are lower and more likely to be constrained by limits. ${ }^{58}$

Rupert Sausgruber and Jean-Robert Tyran conducted a laboratory experiment in which subjects earned income in a game and subsequently voted on a proposal to tax transactions and redistribute revenues. The tax proposal was framed as either a tax on consumers or an equivalent tax on sellers. They showed that the tax was more salient when it was framed as a tax on consumers. ${ }^{59}$ Their study found that participants systemically underestimated the tax burden of the (less salient) tax on sellers and voted for a tax that was not in their self-interest.

The salience of a tax also may be affected by the form in which the tax is levied. The way the tax is framed may make it less prominent. ${ }^{60}$ This is reflected in the study by Chetty and his coauthors as well as the study by Finkelstein: in each case, the same tax was levied in two different forms, one of which was more salient than the other. ${ }^{61}$ In an empirical study comparing the effects of state sales tax exemptions and income tax incentives for the purchase of hybrid vehicles, Kelly Sims Gallagher and Erich Muehlegger found that a sales tax incentive resulted in a significantly larger increase in demand for hybrid vehicles than a comparable income tax incentive. ${ }^{62}$ They attributed this in part to the salience of the sales tax, which was incorporated into the vehicle's price at the time of purchase, as contrasted to the income tax incentive, which

58. Marika Cabral \& Caroline Hoxby, The Hated Property Tax: Salience, Tax Rates, and Tax Revolts 42 (unpublished manuscript), available at http://economics.stanford.edu/files/Hoxby3_2.pdf.

59. Rupert Sausgruber \& Jean-Robert Tyran, Tax Salience, Voting, and Deliberation 2, 11-13 (Univ. of Copenhagen Dep't of Econ., Working Paper No. 08-21, 2008), available at http://ssm.com/abstract $=1292731$.

60. Aradhna Krishna \& Joel Slemrod, Behavioral Public Finance: Tax Design as Price Presentation, 10 INT'L TAX \& PUB. FIN. 189, 190-91 (2004); McCaffery \& Baron, supra note 37, at 290-91. Behavioral responses may vary with the form of the tax even though two taxes are otherwise equivalent. See, e.g., Tomer Blumkin, Bradley Ruffle \& Yosi Ganun, Are Income Taxes and Consumption Taxes Ever Really Equivalent? Evidence from a Real-Effort Experiment with Real Goods (Inst. for the Study of Labor, Discussion Paper No. 5145, 2010), available at http://ssrn.com/abstract=1667769 (finding different behavioral responses to an otherwise equivalent income tax and consumption tax in a laboratory experiment).

61. See Chetty et al., supra note 49, at 1158-64; Finkelstein, supra note 52.

62. Kelly Sims Gallagher \& Erich Muehlegger, Giving Green To Get Green? Incentives and Consumer Adoption of Hybrid Vehicle Technology, 61 J. ENVTL. ECON. \& MGMT. 1 (2011). 
was less well understood and would benefit the purchaser, if at all, only in the following year when a tax return was filed. ${ }^{63}$

Scholars have just begun to focus on the salience aspects of the income tax. One focus has been to demonstrate that an income tax is more salient than other types of taxes. ${ }^{64}$ In a series of survey studies, Edward McCaffery and Jonathan Baron demonstrated that in considering taxes and other fiscal policies, people tended to focus on the most direct, immediate, and certain effects. ${ }^{65}$ One of their conclusions was that people focused primarily on salient effects of taxes. They found that "ordinary people seem to have deep-seated tendencies to form quick judgments on matters of tax and economic policy, responding to the most obviously salient aspect of a choice or decision set." ${ }^{, 66}$ For example, in one experiment they compared raising money for insurance by either an income tax or a payroll or business tax. Despite some attempt to educate subjects on the redistributive effects of the various taxes, respondents preferred the less salient payroll and corporate taxes to the more salient income taxes. ${ }^{67}$

The other empirical work that explores cognitive bias and income taxes focuses on tax rates. There is some evidence that tax rates are not very salient, as evidenced by the fact that people are unable to determine their own marginal tax rates. $^{68}$ If rates were salient, one would expect earnings to respond to changes in rates. Such a response might occur at "kink points" in the rate schedule where marginal tax rates jump. Emmanuel Saez explored that possibility using annual tax return data for several decades. He first examined kink points created by the phase-in and phase-out of the EITC. He found that wage earners did not respond significantly to the EITC incentives created by the phase-out and phase-in. ${ }^{69}$ Self-employed individuals showed significant bunching but only at the first kink point, and the bunching was not consistent. ${ }^{70}$

63. The authors also showed that the effect of the income tax incentive was greatest in the second quarter after tax returns were filed and then declined, which is consistent with a story in which individuals receive imperfect information about the incentive or are poorly informed about the value of the incentive. $I d$. at 2 .

64. See, e.g., McCaffery, supra note 40 , at 1903.

65. McCaffery \& Baron, supra note 37 .

66. Id. at 300 .

67. McCaffery \& Baron, supra note 11, at 1761-65. The authors refer to this as "hidden tax bias." For opinion polls showing similar results, see Andrea Louise Campbell \& Kimberly J. Morgan, Financing the Welfare State: Elite Politics and the Decline of the Social Insurance Model in America, 19 STUD. AM: POL. DEV. 173, 184-90 tbl.2 (2005).

68. See Edwin T. Fujii \& Clifford B. Hawley, On the Accuracy of Tax Perceptions, 70 REV. ECON. \& STAT. 344, 344 (1988) (noting that only $65 \%$ of respondents who completed the survey "were able to provide an estimate of their household's marginal federal income tax rate"). But see id. at 346-47 ("Although taxpayers in general underestimate their marginal tax rates, the difference is modest ....").

69. Emmanuel Saez, Do Tax Filers Bunch at Kink Points? Evidence, Elasticity Estimation, and Salience Effects, 2 AM. J. ECON. POL'Y 180 (2010). He noted that there are explanations for his findings that may have little to do with salience: low intensive elasticity of earnings with respect to marginal tax rates, ignorance of the incentives, inability to adjust labor supply, and inability to misreport earnings. Id. at 196-97.

70. Id. This may be due to the increased flexibility to adjust labor supply or ease in cheating. 
Saez also examined behavioral responses to kinks in the marginal-tax rate schedule and found evidence of a behavioral response to the first kink (that is, from a zero rate to a positive rate) but no evidence of a response at other kink points. Although Saez offers a number of explanations for his findings, one relevant possibility is that it is difficult for taxpayers to understand a complex tax system and the first kink point is "likely to be more salient and easier to understand than other kink points."

There is some literature indicating that average tax rates are more salient than marginal tax rates. ${ }^{72}$ As a result, people probably engage in what Jeffrey Liebman and Richard Zeckhauser call "schmeduling," the act of behaving as if one were facing a misperceived schedule instead of the actual schedule. ${ }^{73}$ The authors found that one variant of this is "ironing," under which an individual perceives an average rate rather than a marginal rate. ${ }^{74}$ Apparently, the individual's actual marginal tax rate is not salient. ${ }^{75}$

Salience also affects the delivery of information to individuals. If a communication is salient, it may convey information that would change behavior. Conversely, a nonsalient communication may fail to convey the necessary information, resulting in no behavioral change. A number of studies have shown that additional information affects decisionmaking. ${ }^{76}$ Chetty and Saez have added to this literature in the tax area by demonstrating that providing additional information about the EITC affects labor supply. ${ }^{77}$ They view their contribution as "showing that the impacts of tax policies depend on the way in which individuals are taught about the tax system."

71. Id. at 211.

72. C.V. Brown, Misconceptions About Income Tax and Incentives, 15 SCOT. J. POL. ECON. 1 (1968); Norbert L. Enrick, A Further Study of Income Tax Consciousness, 17 NAT'L TAX J. 319 (1964); Bruce L. Gensemer, Jane A. Lean \& William B. Neenan, Awareness of Marginal Income Tax Rates Among High-Income Taxpayers, 18 NAT'L TAX J. 258 (1965). These are all survey studies that may or may not reflect the extent to which average tax rates rather than marginal tax rates influence behavior.

73. Jeffrey B. Liebman \& Richard J. Zeckhauser, Schmeduling (Oct. 2004) (unpublished manuscript), available at http://www.hks.harvard. edu/jeffreyliebman/schmeduling.pdf.

74. Liebman and Zeckhauser's example of ironing is an individual with $\$ 80,000$ of wages, who is in a $30 \%$ bracket and pays $\$ 16,000$ of tax, who assumes that his tax rate is $20 \%$, and who will keep $80 \%$ of marginal earnings. Id. at 3. For a similar finding, see Charles A.M. de Bartolome, Which Tax Rate Do People Use: Average or Marginal?, 56 J. PUB. ECON. 79 (1995). Charles de Bartolome ran a laboratory experiment in which he tested whether people used average or marginal tax rates in making investment decisions and found that a significant number used the average rate. He also found that converting tax tables that simply provided taxes without a marginal rate into a schedule that listed the marginal rate increased the number of people who used the marginal rate.

75. This may be in part because taxpayers do not have accurate real-time information. Their marginal tax rate may not be known until year end, and they may use outdated information from a previous year.

76. See, e.g., Esther Duflo \& Emmanuel Saez, The Role of Information and Social Interactions in Retirement Plan Decisions: Evidence from a Randomized Experiment, 118 Q.J. ECON. 815 (2003).

77. Raj Chetty \& Emmanuel Saez, Teaching the Tax Code: Earnings Responses to an Experiment with EITC Recipients (Nat'l Bureau of Econ. Research, Working Paper No. 14836, 2009), available at http:/www.nber.org/papers/w14836.

78. Id. at 5 . 
salience finding was that the information had an effect because it was provided at the time that the individuals were thinking about taxes.

In sum, current work shows that the salience of a tax may affect economic decisions, particularly consumption decisions. If the tax is not very salient, there will be no change in response or less change in response than there would have been had the tax been more visible. Thus, a taxpayer's pretax and after-tax responses will be the same. Ordinarily one would expect the existence of a tax to affect prices and thus demand. With respect to a commodity, a consumer aware of a tax on the commodity will consume less than in the absence of the tax. If the consumer is unaware of the existence of a tax, then the tax will not affect a decision about whether to purchase or the amount to purchase. ${ }^{79}$ In addition, work with respect to the income tax shows that although the existence of this tax is highly salient (virtually everyone is aware of it), some aspects of the income tax-particularly rates-are themselves not very salient.

A caution is in order. Work exploring the relationship of salience to taxation is quite nascent. It is only recently that scholars have begun to explore the effect of cognitive biases on taxpayer decisions. Much of this work has been done in a laboratory setting, and it is entirely possible that taxpayer biases would produce different results in the real world. Furthermore, several cognitive biases may operate at once, and another heuristic may trump a response to salience or may cause it to diminish in importance. Nevertheless, the basic conclusion-salience affects response to taxation-seems fairly robust.

\section{B. Why Do People Ignore (or Misperceive) Taxes?}

In thinking about exploiting salience in designing taxes, it is helpful to understand the various heuristics at work. Several cognitive biases may explain why the increased salience of a tax changes consumer response. ${ }^{80}$ If Congress

79. That is not to say that there are no costs. The consumer who incorrectly perceives the cost of a product where the tax cost is not visible or clear may spend more than she otherwise would on that product. Given a binding budget constraint, she will necessarily spend less on other products, thus distorting her choice.

80. There are cognitive biases other than those attributable to availability that may contribute to the undervaluation or ignorance of taxes. Salience probably does not do all the work. For example, the presentation or framing of prices may affect consumer decisions. See Amos Tversky \& Daniel Kahneman, Rational Choice and the Framing of Decisions, 59 J. BUS. S251 (1986). Anchoring biaswhere an individual anchors decisionmaking to a starting point, failing to adjust to new informationmay cause consumers to presume that the final price is closer to the original price (that is, the anchor) than to some other price. See Tversky \& Kahneman, supra note 45, at 1128. Particularly where consumers are estimating the tax, they may choose a total sales price closer to the posted tax-exclusive price than to the tax-inclusive price. It is also probable that taxpayers are unable to combine the effects of various tax systems, suffering from what McCaffery and Baron call "disaggregation bias." Edward J. McCaffery \& Jonathan Baron, The Humpty Dumpty Blues: Disaggregation Bias in the Evaluation of Tax Systems, 91 ORG. BEHAV. \& HUM. DECISION PROCESSES 230 (2003). This is similar to mental accounting, where individuals account for related items separately. See Richard Thaler, Mental Accounting Matters, 12 J. BEHAV. DECISION MAKING 183 (1999). Finally, optimism bias, which causes a person to undervalue negative effects-like taxes-may cause consumers to undervalue the tax. $C f$. 
were to attempt to use salience as a fiscal tool, it would be helpful to know how deep-seated biases are and whether they can be easily overcome.

The effects of low-salience taxes might be explained by the "isolation effect," which is generally understood to mean that individuals pay attention to information or issues immediately before them and fail to take into account relevant information that is not immediately available. ${ }^{81}$ This explanation assumes that people may have the relevant information but ignore it because it is not immediately available, either because it is not prominent or because there are costs to obtaining the information. Chetty and his coauthors explain their findings by theorizing that individuals incur costs when they must calculate the tax to apply to tax-exclusive prices. ${ }^{82}$ They argue that it is possible that consumers may engage in a kind of cognitive loafing. The existence of the tax is known, but consumers do not take the time to compute the tax-inclusive price of a product, perhaps because the utility gained from not doing the calculation exceeds the savings. Chetty and his coauthors assume rational taxpayers-that is, taxpayers deliberately ignore the tax to avoid the disutility of computing the tax as part of the process of weighing their options. ${ }^{83}$

What might account for this disutility? The most obvious possibility is that the cost of calculating a tax outweighs the benefit of doing so. Even with respect to the sales tax on a single purchase, the value of the time to calculate the total price may outweigh any utility from changing the decision to purchase due to the small amount of tax. If the cost of calculating the tax (including the cost of uncovering the information about the tax and calculating the tax owed) exceeds the cost of ignoring the tax (that is, the amount of the tax), the consumer will not take the tax into account. But, of course, cognitive biases may cause the consumer to calculate the tax incorrectly or even to be ignorant of the need to calculate the tax.

McCaffery and Baron also suggest that taxpayers may ignore "hidden taxes" because of a combination of the endowment effect and loss aversion. ${ }^{84}$ The endowment effect refers to the finding that people value an object they own more than an object they do not. Loss aversion refers to the fact that people consistently are less concerned with failing to gain some amount than they are with losing that same amount; their reaction to the loss is disproportionate to the economic loss. This would explain the reaction to taxes

David A. Armor \& Shelley E. Taylor, When Predictions Fail: The Dilemma of Unrealistic Optimism, in HEURISTICS AND BIASES: THE PSYCHOLOGY OF INTUITIVE JUDGMENT 334 (Thomas Gilovich et al. eds., 2002) (exploring the negative consequences of optimism bias).

81. McCaffery \& Baron, supra note 37, at 290; Edward J. McCaffery \& Jonathan Baron, Thinking About Tax, 12 PSYCHOL. PUB. POL'Y \& L. 106, 107 (2006).

82. Chetty et al,, supra note 49, at 1149 n.6; Raj Chetty, Adam Looney \& Kory Kroft, Salience and Taxation: Theory and Evidence 28-35 (Nat'l Bureau of Econ. Research, Working Paper No. 13330, 2007), available at http://www.nber.org/papers/w13330.

83. Chetty et al, supra note 82 , at 32 . Brian Galle calls this an "intentional model of "hidden taxes." Galle, supra note 2, at 63.

84. McCaffery \& Baron, supra note 37, at 290. 
that are less visible because the incidence is unknown-for example, the employer's contribution to Social Security or corporate taxes-since the taxpayer does not believe that she is losing something that belonged to her. ${ }^{85}$ The tax is not directly paid by the taxpayer, and thus, there is no aversion to losing what she owns. ${ }^{86}$

Another possibility is strategic ignorance. While taxpayers subconsciously know about a tax, they may avoid taking it into account because they know that it might in fact affect their behavior in ways that they would not like. ${ }^{87}$ Inattention may also be attributable to complexity-if a law or provision is extremely complex, one would expect the salience of the law or provision to decrease. ${ }^{88}$ Or a consumer may be unable to compute the tax, and if so, simply ignore it. Another possibility is that taxpayers actually are ignorant of a tax and thus fail to take it into account. ${ }^{89}$ There are a number of possible explanations for this ignorance. People may simply be unaware of the tax. While it is unlikely that individuals are unaware of the existence of, say, a sales tax or an income tax, they may be unfamiliar with the details or various provisions. There are other taxes, however, of which they may be totally unaware-such as the corporate tax or various excise taxes-or at least unaware that the incidence of the tax might fall on them.

\section{Salience and Taxes}

\section{A. Two Kinds of Salience}

Although the literature with respect to salience generally refers to salience as a single type of bias or heuristic causing behavioral responses, it is useful to distinguish between two types of salience. The first behavioral response is a change in individual economic decisionmaking, and this Article refers to the salience that provokes that response as "economic salience." The second is a political response to government action, and this Article refers to the salience that provokes that response as "political salience." A tax or a tax provision may

85. Id. at $289-90$.

86. Id. at 290; see also McCaffery \& Baron, supra note 81, at 119 (observing that taxpayers "do not seem to think this far or this many steps ahead").

87. See Juan D. Carrillo \& Thomas Mariotti, Strategic Ignorance as a Self-Disciplining Device, 67 REV. ECON. STUD. 529, 529 (2000).

88. See Raj Chetty, The Simple Economics of Salience and Taxation I (Nat'l Bureau of Econ. Research, Working Paper No. 15246, 2009), available at http://www.nber.org/w15246 (noting that inattention to taxes may be prevalent "because tax systems are complex and nontransparent").

89. These taxpayers might be said to be "irrational" in that they do not maximize welfare Galle calls this an "unintentional" model of hidden taxes. Galle, supra note 2, at 64 .

90. For a suggestion that the corporate tax is a politically expedient way to raise revenue because its incidence is not understood, see Peter H. Aranson, The Multiple Tax on Corporate Income 45 (Int'l Inst. for Econ. Research, Original Paper No. 71977, 1977). But see Arlen \& Weiss, supra note 38 , at 332 (noting problems with the argument). 
elicit either or both responses. This Section briefly describes both types of salience.

As noted above, most of the empirical work with respect to salience and taxation has examined economic salience and has focused primarily on sales taxes or excise taxes. Economic salience refers to the way in which economic responses or decisionmaking varies with the salience of a tax or a tax provision. The higher the salience, the more pronounced the change in economic behavior. This has been shown to occur with respect to consumption taxes (retail sales taxes and excise taxes). Changes in economic decisionmaking as a result of the imposition of or change in an income tax are less certain. Although the income tax is a very prominent tax, the extent to which it changes economic behavior is less clear. We might assume that if taxpayers were aware of and correctly understood their tax burden, they might supply a different amount of labor than they would in the absence of the tax-much as consumers acquire fewer or different goods in response to a commodity tax. Although it seems likely that laborers would respond in some way to the tax burden, in reality, we cannot be sure of the exact response. This is because it is unlikely that taxpayers accurately assess their tax burden, and because labor supply is more inelastic than consumption purchases.

The second type of behavioral response relies on political salience. This is the political reaction from the electorate in response to the adoption of a tax or tax provision-it might range from rejection to acceptance or, importantly, perhaps no response at all. Although little empirical work has been done to gauge the effect of salience on political response, we can extrapolate from the work on economic salience to infer that the political response to various tax provisions should vary with their salience. ${ }^{91}$ We would expect a more sustained political response to a salient tax or provision, either in support or in protest. $^{92}$ Conversely, there would be less response to a low-salience provision. As contrasted with economic salience, which affects taxpayers directly, political salience elicits a response that is directed at legislators and is intended to affect tax policy. It is assumed that legislators will react to an anticipated or actual political response. ${ }^{93}$ Thus, the viability or acceptance of a tax provision may

91. Although that is what is expected, it is not entirely clear that citizens will protest salient taxes and accept less visible taxes. It is common in the literature to assert that the more visible the tax, the more likely it is that it will be the subject of a protest. But limited empirical data seems to indicate that other factors may predominate. Isaac Martin \& Nadav Gabay, Do Visible Taxes Cause Protest? Tax Policy and Tax Protest in Rich Democracies (Aug. 2, 2007) (unpublished manuscript), available at http://www.mediafire.com/?zrcjoy6hbam.

92. See Richard M. Bird, Visibility and Accountability: Is Tax-Inclusive Pricing a Good Thing?, 58 CAN. TAX J. 63, 65 (2010), available at https://www.ctf.ca/ctfweb/Documents/PDF/2010ctj/10ctj1-bird.pdf (noting that "from a political perspective, people tend to react primarily to the taxes of which they are most aware"); Sausgruber \& Tyran, supra note 59 (finding in a laboratory experiment that salience affects bias voting on commodity taxes).

93. The Canadian experience with the introduction of a highly visible Goods and Services Tax ("GST"), which replaced a much less visible federal-sales tax, is instructive. The low initial rate was 
depend on the political response, which will be influenced by the salience of the provision. For example, a government that was interested in increasing taxes (or revenue) in an environment where that was politically challenging could exploit the availability bias by consciously adopting a low-salience tax provision. Or a political party that wanted to highlight a tax increase proposed by the other party would favor framing it in a salient way so that its prominence would attract attention and perhaps opposition.

Distinguishing between these two types of salience is very helpful in clearing up a recurring confusion about salience and taxes that is best illustrated by a VAT. A VAT sometimes is said to be quite salient. ${ }^{94}$ That would be true when consumers' consumption decisions change due to the presence of the tax. If a price is VAT-inclusive, ${ }^{95}$ consumers are likely to reduce demand for a product subject to the VAT because they will react to the higher price. By contrast, if the price is tax-exclusive (as with many retail sales taxes), consumption decisions should be affected less. In this respect, it would be correct to say that a tax-inclusive VAT has high economic salience because it affects economic behavior. A VAT, however, sometimes is said to be less salient (than, for example, retail sales taxes) ${ }^{96}$ even when it is tax-inclusive. That is because if the tax is built into the price, it is less obvious and voters will notice it less, producing a smaller political response. In this respect, it would be correct to say that a tax-inclusive VAT has low political salience because it evokes less political response.

A particular tax or tax provision may cause both types of responses, and these responses may or may not move in the same direction. The table below illustrates four examples: ${ }^{97}$

reduced twice after adoption due to the hue and cry that accompanied the GST. This was attributed to its visibility and the fact that retailers refused to accept a tax-inclusive pricing option. For the history, see Bird, supra note 92, at 67-69. For somewhat similar stories in other countries, see RICHARD ECCLESTON, TAXING REForms: ThE POLITICS OF THE CONSUMPTION TAX IN JAPAN, THE UNITED STATES, CANADA AND AUSTRALIA (2007).

94. Cf. Janjala Chirakijja et al., The Stimulus Effect of the 2008 UK Temporary Vat Cut 6, 10,
(Nov. 2009) (unpublished manuscript), available http://www.eprg.org.uk/faculty/crossley/research/NTA_volume_VATcut.pdf (discussing the salience of the VAT when prices are and are not tax-inclusive).

95. The European Union, for example, requires that prices be tax-inclusive. See Council Directive 98/6, art. 2, 1998 O.J. (L 80) 27 (EC).

96. See, e.g., Tony Cookson, Should a Government Hide Its Taxes?, THIS YouNG ECONOMIST (Nov. 4, 2009, 7:30 AM), http://blog.thisyoungeconomist.com/2009/1 1/should-government-hide-itstaxes.html (noting that "a value added tax" is "essentially a consumption tax that requires no math at transaction time" and "is less salient" than a retail sales tax); James Pethokoukis, VAT Attack! Another Reason It Is a Bad Idea, REUTERS BREAKINGVIEWS (Oct. 28, 2009, 2:36 PM), http://blogs.reuters.com/james-pethokoukis/2009/10/28/vat-attack-another-reason-it-is-a-bad-idea/ (decrying "the hidden nature of a VAT").

97. This table is intended to be illustrative. Insufficient work with respect to the economic salience of the income tax or various provisions has been done to definitively conclude that the Personal Exemption Phaseout ("PEP") and Pease provisions would not affect economic decisionmaking. Cf. I.R.C. $\$ 68$ (2006) (Pease provision-reducing the allowable amount of itemized deductions for taxpayers whose incomes exceed a statutory threshold); $i d$. $\$ 151$ (d)(3) (PEP provision-reducing the personal exemption for taxpayers whose incomes exceed a statutory threshold). Nevertheless, it seems 


\begin{tabular}{|l|l|l|}
\hline & Low Political Salience & High Political Salience \\
\hline $\begin{array}{l}\text { Low Economic } \\
\text { Salience }\end{array}$ & $\begin{array}{l}\text { PEP and Pease } \\
\text { Provisions }\end{array}$ & Retail Sales Tax \\
\hline $\begin{array}{l}\text { High Economic } \\
\text { Salience }\end{array}$ & Tax-Inclusive VAT & $\begin{array}{l}\text { Marginal Income Tax } \\
\text { Rates }\end{array}$ \\
\hline
\end{tabular}

\section{B. Examples of Salience}

The application of salience to taxes may manifest itself in a variety of ways that affect economic or political salience. It is useful to catalogue some of them.

First, many people who pay a tax may be completely unaware of the tax. Excise taxes on various commodities, which generally are incorporated into the price, are largely unknown. So too are many business-level taxes, such as manufacturers' excise taxes.

Second, individuals may be aware of a tax but unsure of its base. For example, taxpayers may be cognizant of gasoline taxes but unaware of which fuels are subject to them. Or they may be familiar with Social Security taxes but do not know if they apply to fringe benefits as well as wages.

Third, individuals may be aware of the tax but not its incidence. ${ }^{98}$ The structure of the tax affects its salience. For example, both the corporate tax and the payroll tax have low salience for owners and workers because the incidence of the tax is either unknown or not prominent. It is widely believed that the incidence of the corporate tax falls in part on both shareholders and consumers, but the exact degree to which each group bears a burden is controversial. ${ }^{99}$ Perhaps more important for this purpose, one would assume that the overwhelming majority of consumers and owners are unaware that they may share the burden of the corporate tax. If so, their behavioral response to the tax might be different than it would be if the exact incidence were known and

likely that these income tax phase-outs would have little effect on labor supply. Although somewhat more work has been done with respect to marginal income tax rates, this category is only intended to suggest, rather than to conclude, that they might have a significant effect on labor or consumption decisions.

98. The incidence of a tax may not be clear because the tax may cause price changes that shift the burden from the person who remits tax to the government to someone else. An individual may believe that the payor of the tax bears its burden rather than the person with the actual burden.

99. See, e.g., William A. KJein, The Incidence of the Corporation Income Tax: A Lawyer's View of a Problem in Economics, 1965 WIS. L. REV. 576, 602 (concluding that "the question of incidence [of the corporate tax] is wholly unanswerable"); see also Alan J. Auerbach, Who Bears the Corporate Tax? A Review of What We Know, 20 TAX POL'Y \& ECON. 1, 3 (2006) (noting that "the ultimate incidence of the [corporate] tax remains somewhat unresolved," although "there have been many advances over the years in our thinking about how to assign the corporate tax burden"). 
understood. Similarly, many workers are unaware that they bear the burden of both portions of Social Security taxes because the employer's share is passed on to the employee.

Fourth, individuals may be aware of the tax but not know how much tax they pay. The way in which the tax is levied affects salience-the amount of the tax is much less prominent when it is included in a tax-inclusive price than when it is added at the cash register. An excise tax bundled into the advertised price may be difficult to ferret out.

Fifth, individuals may be very aware of a tax and have lots of information about the tax but be unable to calculate their own tax burden, either because they have imperfect knowledge about the rate or the base or because it is too complex. For example, they may confuse marginal rates with average or effective rates.

Sixth, interaction between various provisions may obscure their effects. For example, the top nominal marginal tax rate is quite salient but often does not apply because other provisions, such as income ceilings, rate bubbles, and phase-outs, have the effect of increasing the rate.

Seventh, the consequences of tax provisions also may be masked by other provisions that cut in the opposite direction or by direct spending that counteracts taxation. For example, Congress could heavily tax an industry nominally and at the same time provide tax incentives or direct spending so that the total burden on the industry is of low salience.

Eighth, individuals may not understand the economic effect of a "tax" because it is implicit rather than explicit. For example, where the tax exemption for municipal bonds is fully capitalized into their price (the pretax income is reduced by the statutory tax rate), the holder bears an implicit tax that is never labeled as such.

Ninth, the method of payment of a tax affects its salience. Paying the tax in small, incremental amounts may make the details of the tax far less visible than making a large lump sum payment. Payment of a property tax annually or even quarterly by check makes it more visible, whereas using a tax escrow arrangement in connection with a mortgage makes it less so. ${ }^{100}$

Because the economic salience of income tax provisions is not well understood, and because the thrust of this Article's argument is based on political salience, it is useful to highlight the fact that the current income tax law already contains a number of provisions with low political salience. ${ }^{101}$

100. See Cabral \& Hoxby, supra note 58.

101. There are of course high-salience provisions in the Internal Revenue Code, and there may be occasions where they are warranted. Low-salience taxes or provisions would be counterproductive with respect to Pigouvian taxes that are intended to change behavior. If Congress wants taxpayers to use incentives, it needs to call attention to the benefit. Congress has designed certain provisions in the Code to be more prominent or salient. For example, at one time, the standard deduction and exemption were incorporated into a "zero bracket amount" that was built into the tax tables. Apparently, many taxpayers believed that they had lost those tax benefits because they had been obscured in the calculation of taxes 
There is some evidence that Congress has intentionally designed them with that in mind. These provisions may be of low visibility because they were passed without much fanfare, were not highlighted by the administrative agency administering the provision, and have received little media attention.

For example, withholding on wages is a low-salience way of collecting taxes because wage earners do not make payments directly to the government and usually only observe and receive net pay. Withholding also utilizes several other cognitive biases, such as loss aversion ${ }^{102}$ and easing the burden of economic decisionmaking. ${ }^{103}$ Although observant wage holders may find the tax quite visible because there is evidence of the tax on every pay stub, ${ }^{104}$ payments are made in small, incremental amounts, and their impact is therefore muted.

There also are numerous provisions that have the effect of masking rate increases, and there is some evidence that they were adopted for that reason because directly raising rates was not politically possible. Two examples are the so-called PEP and Pease provisions. The Omnibus Budget Reconciliation Act of $1990^{105}$ increased the effective tax rate for certain taxpayers, but it did not do so directly. Instead, it reduced itemized deductions for high-income taxpayers. Section 68 reduced certain itemized deductions by three cents for each dollar of the amount of adjusted gross income ("AGI") that exceeded an applicable amount. ${ }^{106}$ For each dollar AGI increased, taxable income went up by the dollar plus three cents of eliminated deductions. For those taxpayers with AGI exceeding the applicable amount, their effective tax rate was 1.03 times the statutory rate. For example, a taxpayer in the top $35 \%$ bracket had her

owed. Congress returned to the more salient presentation of those benefits by having taxpayers actually deduct the standard deduction and exemption in calculating taxable income. For another example, see Joel Slemrod, Buenas Notches: Lines and Notches in Tax System Design 21 (Apr. 8, 2010) (unpublished manuscript), available

http://www.law.nyu.edu/ecm_dlv1/groups/public/@nyu_law_website_academics_colloquia_tax_ policy/documents/documents/ecm_pro_065390.pdf ("It may be that notches get people's attention in ways that smooth or kinked programs do not, so that they may be more effective in influencing behavior."). Notches occur when an incremental change in income or expense causes a discrete change in income, deductions, or credits. Congress could design an incentive provision to be of low-salience if it did not actually want to encourage use of the benefit or wanted to limit the revenue cost. In some cases, it appears that Congress intended to provide incentives but designed them in such a way that they are not very salient and are underutilized. See, e.g., Deborah H. Schenk \& Andrew J. Grossman, The Failure of Tax Incentives for Education, 61 TAX L. REV. 440 (2008). A more complete discussion of how exploiting the salience bias might be used in connection with tax expenditures is the subject of a forthcoming paper. See Deborah H. Schenk, Using Cognitive Biases To Curb Tax Expenditures (2011) (unpublished manuscript) (on file with author).

102. Withholding may take advantage of loss aversion because wage earners do not make payments to the government, and therefore, are likely to assume that the portion representing withheld taxes was not theirs.

103. Martin \& Gabay, supra note 91 , at 5.

104. See Gary S. Becker \& Casey B. Mulligan, Deadweight Costs and the Size of Government, 46 J.L. \& ECON. 293 (2003).

105. Pub. L. No. 101-508, 104 Stat. 1388 (codified as amended in scattered sections of 7, 12, $19,20,26,29,30$ and 42 U.S.C.).

106. Id. $\S 11103$ (codified as amended at I.R.C. $\S 68(2006)$ ). 
tax rate increased by slightly over one percentage point on the amount of additional income, for a total tax rate on that income of $36 \%$. This is exactly the same as if Congress had raised the rate one percentage point. That of course would have been much simpler, but at the time it was also politically difficult to do. Thus, Congress intentionally raised the effective tax rate without raising the nominal rate. ${ }^{107}$ This is also true of the personal exemption haircut. ${ }^{108}$ The intention was to increase the effective tax rate for wealthier taxpayers without changing the top marginal rate. ${ }^{109}$

An earlier example of this was found in the Tax Reform Act of 1986, which imposed a $5 \%$ surcharge on certain middle-income taxpayers to phase out the benefits of lower brackets. This effectively created a higher bracket that for some taxpayers was wedged in the apparent top bracket. This enabled Congress to assert that the top marginal tax bracket was lower than it actually was. $^{110}$

On a broader level, all phase-outs can be seen as a form of adjusting marginal rates without actually changing the nominal rates. They serve another purpose as well. When Congress phases out or imposes caps on deductions, it is still able to retain the deduction even though it has become far less valuable. For example, limiting the deduction for business meals and entertainment to $50 \%$ of the $\operatorname{cost}^{111}$ leaves the deduction in place but effectively raises the tax rate on all those who incur the costs. There is no change, however, in the marginal rate schedule. ${ }^{112}$

A failure to index rate brackets for inflation also has the effect of changing the top marginal rate for many taxpayers without making any changes in the rate brackets, assuming income increases with inflation. In periods of inflation, taxpayers will move up the rate brackets - and thus, their taxes will increase- even though their purchasing power has remained steady. ${ }^{113}$ This tax "increase" has almost no salience because its source is not obvious. It takes a fairly savvy taxpayer to understand that an increase in inflation will have this effect. And, perhaps more importantly, it is not directly traceable to Congressthe failure to address inflation is not a specific act that is likely to become the

107. Steuerle \& Sullivan, supra note 38 , at 407 .

108. I.R.C. $\S 151(\mathrm{~d})(3)$.

109. Steuerle \& Sullivan, supra note 38 , at 407 ("In reality, it was designed mainly to increase tax rates-but without the increase being so obvious as to be reflected in the formal rate schedule.").

110. For example, the Joint Committee explanation of the bill noted that there would be only two brackets, $15 \%$ and $28 \%$, failing to mention the $33 \%$ bracket created by the rate bubble. STAFF OF THE JONT COMM. ON TAXATION, 99TH CONG., GENERAL EXPLANATION OF THE TAX REFORM ACT OF 1986, at 20-21 (1987).

111. I.R.C. $\S 274(\mathrm{n})$.

112. These "backdoor" ways of increasing tax rates have been subject to withering criticism. See AM. BAR ASS'N Section of TAXATION, RePORT to THE ABA HousE of Delegates (1999), available at http://www.abanet.org/tax/pubpolicy/resolutions/subl51d3.html (advocating repeal of the PEP and Pease provisions and calling for explicit rate adjustments as a more transparent approach); McCaffery, supra note 40, at 1900-01.

113. See McCaffery, supra note 40 , at 1893-97. 
focus of political debate. This remained true until the 1970s when inflation became so insistent that there was a call to deal with what was referred to as inflation creep. The 1981 Tax Act indexed rate brackets, but it was not fully implemented until 1989. ${ }^{114}$ At that point, the salience of inflation overpowered the low salience of inflation creep, although that has reversed in recent years. ${ }^{115}$ Another way to adjust the rates without doing so directly is to adjust downwards the income subject to a higher rate bracket. Even if a taxpayer does not change rate brackets, the extra income will be taxed at her marginal tax rate, increasing the effective tax.

Perhaps one of the most important ways Congress has devised to increase revenue with low political salience is the alternative minimum tax ("AMT"). The original purpose of the AMT was to ensure that high-income individuals paid at least some income tax and to increase the effective tax rate on highincome individuals. ${ }^{116}$ AMT is calculated by determining alternative minimum taxable income ("AMTI") ${ }^{\mathrm{i} 17}$ and reducing it by phased-out exemption amounts to calculate the taxable excess, on which the tax is levied. ${ }^{118}$ If the tentative minimum tax is greater than the regular tax, the taxpayer owes the difference. ${ }^{119}$ Once the AMT is taken into account, actual marginal tax rates are no longer very salient due largely to the complexity of the statutory provisions. ${ }^{120}$ Because of the interaction of the AMT with the regular tax rate schedule, as well as the fact that the AMT base and regular base differ, it is difficult for taxpayers to determine their actual marginal rate. ${ }^{121}$

114. Economic Recovery Tax Act of 1981, Pub. L. No. 97-34, $\S 104(a), 95$ Stat. 172, 188 (codified as amended at I.R.C. $\S 1(\mathrm{f})$ ); see also Rev. Proc. 88-56, 1988-2 C.B. 726 ("Starting with taxable years beginning in 1989 , both the tax rate tables and the standard deduction amounts are subject to an inflation adjustment based on a prescribed method.").

115. On the decreasing salience of inflation, see, for example, Janet L. Yellen, President \& CEO, Fed. Reserve Bank of S.F., Remarks at the Federal Reserve Bank of Boston Conference on the Implications of Behavioral Economics for Economic Policy: Implications of Behavioral Economics for Monetary Policy 7 (Sept. 28, 2007), available at http://www.frbsf.org/news/speeches/2007/0928.pdf.

116. Congress was outraged by 154 individuals with incomes of over $\$ 200,000$ who paid no tax in 1966. H.R. REP. No. 91-413, at 1 (1969), reprinted in 1969 U.S.C.C.A.N. 1645, 1645. In addition, many individuals with high incomes were paying tax at a relatively low effective rate due to a variety of tax preferences, even to the point where the tax rates were regressive at the top end. STAFFS OF THE JOINT COMM. ON INTERNAL REVENUE TAXATION \& THE COMM. ON Fin., 91ST CONG., SUMMARY OF H.R. 13270, THE TAX REFORM ACT OF 1969, at 47 (1969).

117. AMTI is calculated by adjusting income according to I.R.C. $\S \S 56$ and 58 , and adding the tax-preference items in $\S 57$.

118. I.R.C. $\$ 55$ (a). The tentative minimum tax equals (1) $26 \%$ of taxable excess less than $\$ 175,000$, plus (2) $28 \%$ of taxable excess greater than $\$ 175,000$. Id. $\S 55(\mathrm{~b})$.

119. Id. $\S 55(\mathrm{a})$. There are four current effective AMT rates (due to phase-out of the exemption), which are $26 \%, 28 \%, 32.5 \%$, and $35 \%$. Once the phase-out range is passed, the marginal tax rate is $28 \%$. Id. $\$ 55(\mathrm{~b})(1)(\mathrm{A})(\mathrm{i})(\mathrm{II})$.

120. Williams, supra note 30 (noting that complexity causes a reduction in tax awareness and using the AMT as an example).

121. See Linda M. Beale, Congress Fiddles While Middle America Burns: Amending the AMT (and Regular Tax), 6 FLA. TAX REV. 81 1, 824-25 (2004) (criticizing the AMT for this feature); Leonard E. Burman, William G. Gale \& Jeffrey Rohaly, The AMT: Projections and Problems, 100 TAX NOTES $105,116(2003)$ (same). 
The economic salience of the AMT is somewhat ambiguous. It is likely that many taxpayers ignore the AMT calculus in making decisions in which they take their marginal tax rate into account (assuming tax rates affect economic behavior). ${ }^{122}$ On the other hand, the political salience of the AMT has been quite low. It is the nominal marginal tax rates that are a regular part of political discourse. In fact, it is the highest rate that garners all the attentionvirtually no attention is paid to the other rate brackets. Furthermore, the aversion to "raising taxes" almost entirely focuses on changes in the rate brackets, ignoring the possibility that other changes-such as adjustments to the base-are equivalent ways to raise taxes. Thus, what is salient is the top nominal marginal rate. Other marginal rates and an individual's actual marginal rate have low political salience. ${ }^{123}$ Therefore, the focus on the top marginal rate bracket, with high political salience, permits Congress to effectively increase tax rates by using provisions with low political salience, like the AMT.

The low salience of the AMT does not occur because the tax is hidden or people are unaware of it. ${ }^{124}$ Politicians have done a good job of making people understand that it exists-largely through trumpeting their success in curbing its growth. But the details and, specifically, the effect on marginal tax rates, are almost completely ignored. It is the effect of the AMT, rather than the tax itself, that has low salience. Many people do not know if the AMT applies to them. But more importantly, even if they know that they may be subject to the AMT, they are unaware of how it specifically affects their tax burden. For example, someone who is in the $24 \%$ marginal tax bracket for the regular tax may believe that $24 \%$ is her marginal rate even though the actual marginal rate may be higher due to the AMT. ${ }^{125}$ Thus, taxpayers' political response does not change in the way that it might if they were aware of their actual marginal rate, and any revenue that the government might lose from changing the nominal rate brackets is retained.

122. This is probably a good example of "schmeduling." See Liebman \& Zeckhauser, supra note 73 . Liebman and Zeckhauser argue that one of the conditions that gives rise to schmeduling is complexity and give schedule complexity as an example, by which they mean "when there are more rates in the schedule or two or more schedules operate simultaneously." Id. at 4.

123. Many taxpayers are confused about the difference between marginal rates and effective or average rates; even if they know in which rate bracket they fall, they mistakenly believe that all income is taxed at one rate. Or they may believe that all income is taxed at the average rate. The AMT further confuses this because it is difficult for individuals to calculate the highest marginal tax rate or their own individual marginal tax rate. An added low-salience feature of the AMT is that it breaks the taxes into multiple pieces, making each piece less salient than the total.

124. The "acceptance" of the AMT may be a result of multiple cognitive biases. For example, individuals may be unable to aggregate the regular tax with the AMT-partitioning the total tax bill into two parts may cause taxpayers to underestimate their actual tax burden. Anchoring bias may also do some of the work. Taxpayers are likely to anchor their estimate of tax burdens in the regular tax with its well-known marginal tax rates and be unable to adjust even when presented with additional information.

125. It is extremely difficult to determine the actual marginal rate in advance if the taxpayer is subject to the AMT. This is largely because of various phase-outs, such as the exemption amount. If the rate cannot be determined until the tax return is filed, it is the perceived marginal rate rather than the actual marginal rate that will affect behavior. 


\section{Salience as a Fiscal Policy Tool}

\section{A. The Argument and Examples}

Generally, commentators assume that cognitive biases lead to poor decisionmaking, inefficiencies, and other problems (catalogued below) and that either public or private correctives are in order. ${ }^{126}$ The consensus is that legislators should not take advantage of cognitive biases in designing taxes. ${ }^{127}$ This Article argues, however, that there are circumstances where it is appropriate for legislators to do so. ${ }^{128}$ The main argument that this Article makes is a political-economy argument-namely, it is appropriate to exploit political salience. Before laying out the argument, this Section considers whether there is an efficiency case for exploiting economic salience.

126. See, e.g., McCaffery \& Baron, supra note 81, at 110,127-28. McCaffery and Baron argue that "hidden taxes" will cause citizens to underreact to a loss of the money taken by such taxes, which will ultimately lead to less utility and a loss of wealth. They also note that the so-called "flypaper effect" will cause hidden taxes to stick, raising new revenue rather than replacing other sources of revenue. For further discussion of the "flypaper effect," see James R. Hines Jr. \& Richard Thaler, The Flypaper Effect, 9 J. ECON. PERSP. 217 (1995). But see Elizabeth Becker, The Illusion of Fiscal Illusion: Unsticking the Flypaper Effect, 86 PUB. CHOICE 85, 86 (1996) (finding "no evidence of irrational behavior" that would support the flypaper-effect hypothesis). McCaffery and Baron recommend education (debiasing), political constraints (for example, PAYGO), and structural reform (for example, competition in tax design). McCaffery \& Baron, supra note 81, at 129-32.

127. Some commentators directly reject the possibility. See Leo P. Martinez, Tax Legislation and Democratic Discourse: The Rhetoric of Revenue and Politics, 4 NEV. L.J. 510, 516 (2003) (arguing that "the resort to taxes that are not on the public's radar screen . . can only delay what will inevitably be a rebellion against these heretofore "silent taxes"'); McCaffery, supra note 40, at 1931, 1943 (calling the use of cognitive biases "tricks" and the approach "fraught with dangers" and "run[ning] afoul of basic moral notions" and stating that the author is "uneasy at the prospect of exploiting cognitive error as a general approach"). Others use terminology that makes it clear that they think it is a bad idea. See, e.g., Congdon et al., supra note 38, at 6 (raising the possibility that policymakers could affect welfare outcomes by "deliberately manipulating tax salience"); Tino Sanandaji \& Björn Wallace, Fiscal lllusion and Fiscal Obfuscation: An Empirical Study of Tax Perception in Sweden (Research Inst. of Indus. Econ., IFN Working Paper No. 837, 2010), available at http://www.ifn.se/wfiles/wp/wp837.pdf (coining the term "fiscal obfuscation" and noting that "[o]bfuscation relates to the politicians exploiting the public's rational ignorance by hiding information from them through indirect policies"); Ted Gayer, Behavioral Economics and the Conservative Critique of VAT, TAXVOX (Oct. 28, 2009, 1:23 PM), http://taxvox.taxpolicycenter.org/blog/_archives/2009/10/28/4364151.html ("[T]he risk is that policymakers will use these insights [of behavioral economics] to deliberately temper healthy economic and political constraints on the growth of government."). Aradhna Krishna and Joel Slemrod raise the normative issue but do not clearly take a position. Krishna \& Slemrod, supra note 60, at 198-99.

Generally, commentators also assume that increased salience is beneficial. See, e.g., Susan Cleary Morse, Using Salience and Influence To Narrow the Tax Gap, LoY. U. CHI. L.J. 483, 500 (2009) (offering proposals to make communications from the IRS more salient-that is, relevant, prominent and accessible - to close the tax gap).

128. For other largely undeveloped suggestions that it might be acceptable to deliberately employ low-salience taxes, see Galle, supra note 2, at 98 ("[W]e might employ hidden taxes only at the federal level. . . . Using only national-level hidden taxes would thus avoid a number of the allocational distortions . . . "); Steven M. Sheffrin, What Does the Public Believe About Tax Fairness?, 45 NAT'L TAX J. 301, 306 (1993) (noting that "there may be scope for using their characteristic biases in the name of good tax policy"); and Williams, supra note 30 (suggesting that masking taxes may help to raise revenue in a relatively efficient way). 
Those who have considered the possibility that exploiting the salience bias may be efficiency-enhancing have done so in the context of consumption taxes. ${ }^{129}$ The basic argument is that if individuals are unaware of a tax, it cannot change their pretax behavior. Usually a behavioral response reduces the efficiency with which resources are used, decreases output, and diminishes utility. It is often suggested that efficiency costs can be reduced by imposing taxes on inelastic goods or behavior because price is less important or irrelevant. If individuals are unaware of or ignore low-salience taxes, and thus, the taxes operate in the same way as a tax on highly inelastic behavior, they might be relatively efficient because they would not affect the behavior of actors. Under this view, low-salience taxes might be said to promote efficiency. ${ }^{130}$

With respect to consumption taxes, however, there are offsetting considerations that make efficiency gains uncertain. Distortions created by taxes may be magnified with low-salience taxes because taxpayers will not make consumption decisions with correct information. If individuals are confused rather than ignorant about taxes, there may be no efficiency advantage. For example, if individuals were not sure there was a tax, they might act as if a tax were imposed whether there was a tax or not. If consumers were unaware of the tax, they would incorrectly calculate prices and thus might consume more of the goods subject to the tax. With a binding budget constraint, they would consume less of other goods, thus distorting choice. ${ }^{131}$ If consumers were unable to calculate the amount of the tax, they might assume a larger or smaller price adjustment than actually occurs. Thus, the efficiency effects of decreasing salience with respect of consumption taxes are ambiguous.

The efficiency gains from the use of low-salience income tax provisions are somewhat less ambiguous. As noted above, almost all consumers will be aware of the income tax, so the possibility that there are efficiency gains because of ignorance of the tax itself does not hold. Furthermore, individuals will not be subject to a binding budget constraint since income is not fixed. The efficiency effects with respect to the income tax depend on the extent to which taxpayers alter their economic decisions in response to the tax. The empirical

129. See Galle, supra note 2, at 62; Congdon et al., supra note 38, at 8; Nussim, supra note 38 .

130. Galle suggests but does not wholly support the idea that such taxes may be a desirable feature of a tax system because they are efficient. His specific policy prescription is that "hidden" taxes are likely to be welfare-increasing on goods for which demand is inelastic, and welfare losses that result from transfers from poorer consumers to richer consumers can be minimized by using hidden taxes in markets where those who benefit from a hidden tax are no wealthier than those who might lose welfare. Galle, supra note 2 , at 62.

131. See Congdon et al., supra note 38 , at 8 . William Congdon, Jeffrey Kling, and Sendhil Mullainathan note that taxes that are hidden from taxpayers will keep elasticity low; if there is a binding budget constraint, spending more on the item with the low-salience tax leaves less income for other purchases and thus distorts consumption and decreases welfare. They conclude that the net consequences are not clear. 
evidence on that issue is mixed. While theoretically wage earners should adjust their labor supply in response to taxes, it is not clear whether that actually occurs or the extent to which it occurs. Many factors make it very difficult to determine the degree to which a change in tax affects the supply and demand for labor. ${ }^{132}$ They include labor elasticities (which vary by gender and marital status ${ }^{133}$ ), the type of work offered, decisions about education and training, the selection of an occupation, and the interaction of the income and substitution effects. If we assume that labor supply would decrease with a tax increase, we might assume that a low-salience income tax provision would result in less of a decrease (and a provision with no salience might result in no decrease). If so, such a provision would be efficiency-enhancing. If labor supply were not affected by tax changes, a low-salience provision would not increase efficiency; conversely, however, it would not decrease efficiency.

The degree to which a low-salience tax provision is efficiency-enhancing is even more complicated because we do not know how much a tax change affects labor supply. That is dependent on a number of factors. One important factor is that many wage earners likely cannot correctly calculate their income tax burden. ${ }^{134}$ The tax burden they calculate may affect their choice of the mix between labor and leisure. If individuals assume that they owe more in taxes than they do (because, for example, they incorrectly assume that the marginal rate applies to every dollar earned or because they assume they are in the top (salient) bracket when they are not), they may undersupply labor. Under this view, if decreasing distortion with respect to taxes is desirable, salience is required. Conversely, there may be efficiency benefits to be gained where individuals are unaware of their marginal tax rates and instead use average rates. ${ }^{135}$ Because average rates are lower than marginal rates, individuals would supply more labor than they would if confronted with the actual marginal rate, decreasing excess burden.

132. For an excellent review of the empirical literature and the reasons the conclusions are tentative, see CONG. BUDGET OFFICE, LABOR SUPPLY AND TAXES (1996), available at http://www.cbo.gov/ftpdocs/33xx/doc3372/labormkts.pdf. See also CONG. BUDGET OFFICE, THE EFFECT OF TAX CHANGES ON LABOR SUPPLY IN CBO'S MICROSIMULATION TAX MODEL 1 (2007), available at http://www.cbo.gov/ftpdocs/79xx/doc7996/04-12-LaborSupply.pdf (noting the limits of models that estimate the effect of taxes on labor supply and demand).

133. See generally Francine D. Blau \& Lawrence M. Kahn, Changes in the Labor Supply Behavior of Married Women: 1980-2000, 25 J. LABOR ECON. 393, 395 (2007) (noting that married women have historically exhibited higher wage elasticities than their husbands, although the gap has narrowed in the past several decades).

134. See Kotlikoff \& Rapson, supra note 42, at 1.

135. The authors of two papers that assert that many individuals make economic decisions based on average rather than marginal tax rates both make the claim that this may improve welfare. Because average rates are lower than marginal rates, individuals supply more labor than they would if confronted with the actual marginal rate, decreasing excess burden. See de Bartolome, supra note 74, at 82; Liebman \& Zeckhauser, supra note 73, at 26. De Bartolome appears to support the use of the misperception. See de Bartolome, supra note 74, at 82 ("Maintaining the misperception is good public policy."); see also Naomi Feldman \& Peter Katuščák, Should the Average Tax Rate Be Marginalized? (Ctr. for Econ. Research \& Graduate Educ.-Econ. Inst., Working Paper No. 304, 2006), available at http://195.113.12.58/pdf/wp/Wp304.pdf (noting welfare gains from the misperception of rates). 
While it seems likely that a low-salience income tax provision would increase efficiency more than a low-salience consumption tax provision, the conclusion that a low-salience income tax provision is efficiency-enhancing is not sufficiently robust to be the sole support for intentionally exploiting the salience bias.

A much stronger case can be made for intentionally exploiting political salience. There are circumstances where Congress should take advantage of the cognitive bias created by salience as a fiscal tool for political-economy reasons. ${ }^{136}$ Assuming that the state has the power to levy taxes and an appropriate need for revenue, it is proper for it to choose a form that is most palatable to its citizens. In other words, low-salience taxes may serve other, more important goals. This is an instrumentalist argument-exploiting the salience bias may achieve an important end.

There is a strong relationship between tax salience and political support for taxation. Salience affects the politics of taxation. It is foolish and counterproductive to divorce taxation from politics. Accepting both that the citizenry wants public goods (and perhaps, redistribution) and that they abhor taxation, ${ }^{137}$ it is appropriate for the government to use fiscal tools that can accomplish the revenue goal with the least pain and most acceptance.

While we might presume that this will be in the interest only of legislators seeking reelection, ${ }^{138}$ it also may be entirely beneficial to citizens seeking to avoid the psychic pain of paying taxes. ${ }^{139}$ The limited literature on salience and the politics of taxation assumes that the benefit of taking salience into account runs entirely to legislators. The Finkelstein study suggests, for example, that decreasing the salience of tolls through the collection mechanism reduces the political costs of raising toll rates. ${ }^{140}$ The so-called leviathan literature,

136. This argument is limited to legislation. Whether it is appropriate to take salience into account with respect to regulations involves different considerations and is beyond the scope of this Article.

137. See infra Section VI.A.

138. See AMOTZ MORAG, ON TAXES AND INFLATION 21 (1965) (suggesting that less visible taxes are better on both psychological and economic grounds and that "[a]n important factor in the realities of the limits of taxation are the psychic costs of paying tax, costs which politicians will carefully heed because they are clearly relevant to the prospects of re-election").

139. Given the inevitability of taxation, taxpayers may prefer taxes that are less visible. A survey conducted in Canada after the adoption of the GST indicated that Canadians preferred to have the GST included in the price. See RICHARD M. BIRD, WhERE Do WE Go From HERE? ALTERNATIVES TO THE GST 13 (1994) (noting that "Canadians may not agree on how much they like the government, the tax structure, or the GST, but they agree they cannot stand to be reminded of the GST every time they make a purchase"). The experience in Japan, which switched from optional tax-exclusive pricing to mandatory tax-inclusive pricing, also bears this out. Although an overwhelming majority of registrants initially opted for tax-exclusive pricing (quoting the tax separately), ultimately most shifted. See HIROMITSU ISHI, THE JAPANESE TAX SYSTEM 291 (3d ed. 2001) (noting that consumers preferred "to pay the tax without noticing the tax burden"). In 2004, the Japanese government mandated tax-inclusive pricing. Kotaro Tsuru, Significance of Showing Net Prices That Include Consumption Tax: With a View to Improving Business Productivity, RESEARCH INST, OF ECON., TRADE \& INDUS. (Feb. 17, 2004), available at http://www.rieti.go.jp/en/columns/a01_0117.html.

140. Finkelstein, supra note 52, at 1009. 
discussed below, assumes that politicians are revenue-maximizing and interested solely in their own reelection. While it is entirely possible that politicians who favor low-salience taxes will be rewarded with reelection, this Article argues that there is an additional benefit as well: a political acceptance of taxes by the populace. In fact, taxpayers may fail to reward or penalize politicians because they are ignorant of various tax provisions or because they intentionally ignore them.

This is not to suggest either that Congress should always adopt lowsalience taxes ${ }^{141}$ or necessarily that a low-salience tax will be the most palatable to the populace. Rather, the argument is that it is appropriate for Congress to take salience into account as a fiscal policy tool. We cannot be certain that there will be a political response to the salience of a provision; we also cannot be certain that a response to a low-salience provision will be muted. We simply do not know the extent to which salience may be the only or the determining factor in a political response to a tax provision. ${ }^{142}$ But there is no reason to believe that it is wrong for Congress to consider salience in designing taxes.

\section{B. The Relationship Between Transparency, Complexity, and Salience}

Transparency, complexity, and salience are linked concepts. In the case of low-salience taxes, transparency and complexity concerns impose limits on the ability of legislators to exploit the salience bias.

Transparency in governance is generally a virtue and at first glance may appear to complicate Congress's ability to use low-salience taxes. But a lack of transparency in governance is not essential to the case for exploiting the salience bias and may even be counterproductive. The argument for using lowsalience taxes is that they make raising revenue palatable to the citizenry-not that the citizenry should be tricked. If the goal is to obtain the acceptance of a tax, adopting it in the shadows is not likely to be nearly as effective as adopting it in the sunlight. Thus, a key to the consent to the use of low-salience provisions is the knowledge that they are not hidden and information about them can be obtained. While the parameters of transparency are necessarily fuzzy, the fact that legislation is adopted in public view is necessary. What is not necessary, however, is that Congress explain that it is using a low-salience provision or why it is doing so, as long as it is possible to obtain the legislation

141. Clearly, the sole use of low-salience taxes or changes ultimately will backfire. Cumulatively, when the taxes or changes become large enough, either tax aversion will kick in or taxpayers will act rationally and will take them into account. See Galle, supra note 2, at 84 (arguing that "the rational model likely implies that hidden taxes cannot be a major component of government budgets").

142. See Alan J. Auerbach, Public Finance in Practice and Theory, 56 CESIFO ECON. STUD. $1,6(2010)$ ("[W]e have little evidence regarding the effects of [low-salience] provisions on such a grand scale, or about whether the salience of tax provisions changes over time."). 
and figure out its effect if one wanted to do so. Like other instrumentalist approaches, the use of low-salience taxes incorporates a process value critical for democratic legitimacy. ${ }^{143}$ It is important to note that this approach does not enshrine private advantage or private agendas. Whether the government should raise revenue and how much will be determined in the public sphere.

For instance, although there has been much academic complaint about the adoption of the PEP and Pease provisions, they are a very good example of when using a low-salience provision may be desirable. If it was impossible for Congress to raise the marginal tax rates directly, using phase-outs may have accomplished the same thing in a politically viable way. For Congress to have emphasized that the effect was identical to raising the marginal rate would have defeated its purpose. However, so long as the provisions were adopted publicly and their effect could be understood (which it was), the transparency criterion was satisfied.

The role of complexity is more complicated. Increasing the complexity of a statutory provision is one way that legislators can decrease its salience. The statutory language itself can be quite complex, making it difficult to understand. Or the interaction of one provision with another provision can limit understanding. Or giving a taxpayer a choice between multiple credits or deductions can make decisionmaking complicated. Thus, the utility of using low-salience provisions may fly in the face of a desire for less complexity. That requires legislators to evaluate the tradeoff between the costs of additional complexity and political acceptance. We often assume that complexity is undesirable, but there may be cases where that is not so. ${ }^{144}$ There may be situations where political acceptance is more important than simplicity. But in exploiting the salience bias, legislators should not assume that complexity is their only tool, and they must be careful to use it only when necessary. As noted previously, it is possible to create taxes with low political salience that are not very complex - for example, a tax-inclusive VAT or the employer's portion of Social Security. Furthermore, the use of too much complexity to limit salience may backfire because it may raise political hackles simply because taxpayers cannot understand their obligations or must incur unacceptable costs to determine them.

143. See infra Part V.

144. Section 469 is a canonical example of a complex statute, and its regulations had the highly desirable effect of shutting down individual tax shelters in the 1980s-perhaps in part due to their complexity. The tradeoff was warranted. See George K. Yin, Getting Serious About Corporate Tax Shelters: Taking a Lesson from History, 54 SMU L. REV. 209, 218-19 (2001). 
V. Responding to Criticisms of Exploiting the Salience Bias

This Part briefly reviews the criticisms directed against exploiting the salience bias and concludes that none of them is strong enough to preclude intentionally taking salience into account. ${ }^{145}$

\section{A. The Deliberate Use of Low-Salience Tax Provisions Is Undemocratic}

Intentional exploitation of cognitive errors-for example, ignoring nonsalient information-might be said to fly in the face of democratic notions. It seems to show disrespect on the part of the legislature toward the people and exploits ignorance. ${ }^{146}$ The result is that legislators fail to act on voter preferences. This argument might be restated as follows: (1) the government has the power to raise revenue and the power to decide the exact form in which to do so; (2) the government understands that both Method A and Method B will raise $\$ \mathrm{X}$ in revenue; (3) the government also believes that Method $\mathrm{A}$ is more politically viable because it is preferable to voters since it is less prominent and therefore less painful; and (4) although the government could choose to use Method A by publicly passing legislation (thereby satisfying the transparency criterion), it would be undemocratic to do so.

There are a number of responses to this critique. Broadly, this criticism is directed at any instrumentalist approach and, taken to the extreme, would prohibit the state from taking into account many means to accomplish legitimate government goals. But the essence of government is to weigh problems and the tradeoffs of various approaches. The use of low-salience provisions is essentially a tradeoff between the benefits to be gained from government paternalism and the possible undemocratic nature of exploiting citizen ignorance or indifference. ${ }^{147}$ If Congress believes that raising additional revenue is an important goal, there is no reason that it cannot do so in a way that the people find acceptable.

145. It is worth noting that criticism is directed at low-salience taxes rather than high-salience tax provisions, which raise different concerns. See supra note 101 .

146. See Bird, supra note 92 , at 76 (noting, in support of tax-exclusive prices rather than taxinclusive prices, that "hiding the tax bill does not seem a particularly attractive way to build a sustainable democratic consensus in support of fiscal equilibrium"); Galle, supra note 2, at 109 (discussing "government by deception"); Gillian Lester, Can Joe the Plumber Support Redistribution?, 64 TAX L. REV. (forthcoming 2011) ("[T]he overarching normative question [is] whether I advocate achieving policy change by using techniques from behavioral psychology to, in essence, mislead people ... . The answer is no: to advocate such a position would be troubling from the perspective of democratic legitimacy."); McCaffery, supra note 40, at 1943.

This critique is very different from that which considers "the wisdom and legitimacy of government decisions made out of public sight but supposedly for the public good." See Galle, supra note 2 , at $109 \&$ n.235. In this Article's lexicon, low-salience taxes may result from transparent government decisions.

147. There also may be a tradeoff between distortions caused by citizens acting on incomplete information (and thus making poor consumption choices) on the one hand, and beneficial increases in revenue on the other. 
The argument that relying on cognitive bias shows disrespect for the people must be taken to mean that use of low-salience taxes does not reflect voter preferences. A second problem with the anti-democracy claim relates to the difficulty of discerning voter preferences and determining which preferences should be taken into account. The claim focuses only on voter preferences with respect to taxes. Even assuming that we know what those preferences are (more on this below), it ignores voter preferences with respect to spending. It seems clear that voters want extensive government programs. Despite some rhetoric about "big government" and runaway spending programs, there is little support for making significant cuts that would have a positive effect on the deficit. Voters therefore are sending conflicting signals to their representatives: they want programs but they do not want to pay for them. Their preferences on taxes are clear only if we sever taxes from spending; their preferences on spending are clear only if we sever spending from taxes.

But neither approach makes sense under democratic theory since spending and revenue are inevitably intertwined. In order to carry out voter preferences, the government needs to know whether citizens are willing to pay $\$ X$ for Program $\mathrm{Y}$-something they usually do not know. It is impossible for legislators to ascertain whether "we want Program $Y$ " or "we do not want to pay $\$ X$ in taxes" represents true preferences. It is not clear therefore that levying a low-salience tax or adopting a low-salience provision that produces $\$ \mathrm{X}$ in revenue fails to carry out voter preferences. Suppose the government does not adopt the tax and instead cuts Program Y? Is that more democratic?

Another alternative is the current approach-retain Program $\mathrm{Y}$ but raise less than $\$ \mathrm{X}$ in revenue. Ultimately, that may result in bankruptcy (as is practically the case for some states) or fiscal collapse. That too has enormous costs, and it is certainly not clear that voters prefer this result over raising $\$ \mathrm{X}$ in a low-salience way. Suppose the government does not raise $\$ X$ in direct revenue and does not cut spending for Program $\mathrm{Y}$ but pays for it through inflationary deficit spending. The reduction in purchasing power caused by the inflationary effect of deficit spending is akin to a tax-one that is even less politically salient than direct taxation. Why should we assume that voters would prefer deficit spending rather than low-salience direct taxation?

Even limiting the claim to preferences with respect to taxes, determining voter preferences is challenging. Calculating voter preferences in general is difficult enough; understanding voter preferences on policy issues is even more complex because those preferences are not always observable, and thus, a proxy must be used. Even in the case where policy issues are salient and part of a campaign, voting for a particular candidate may obscure voter choice. For example, suppose a candidate supports lower taxes, gun control, and abortion choice and wins the election. We cannot be sure that all those who voted for the candidate support lower taxes; some may have voted solely with respect to the candidate's position on abortion or guns. And even if we knew that all those who supported the candidate did so because of her strong position on lower 
taxes, that does not tell us exactly how the electorate wants her to vote on the design of a tax system.

It is also possible that citizens prefer to be "fooled," that is, that their actual preference is for a low-salience tax or provision. It seems entirely possible that voters are aware of the need for revenue but have a high aversion to taxes, and thus, prefer the taxes to come in a form that is less unpleasant by being less noticeable. Otherwise, they may bear a cognitive cost-a form of tax aversion-by being confronted with the tax. Assume that the fiscal illusion, discussed below, is correct. That is, legislators are revenue-maximizing and will continually seek to raise nonsalient taxes with as little attention as possible. And also assume, as discussed below, that over time taxpayers debias - that is, they come to understand that this is what legislators will do and expect them to do so. ${ }^{148}$ It follows that if low-salience taxes persist, this approach must be the preference of voters, ${ }^{149}$ meaning they prefer to raise revenue by low-salience taxes. There is some evidence of this with respect to Social Security taxes, where there seems to be a preference for splitting the notional burden of the tax between employers and employees although the incidence falls on employees. ${ }^{150}$ If that is voters' preference, the anti-democratic claim does not hold.

Another response to the anti-democratic critique is instrumental. Law is designed to encourage or incentivize certain behavior. In this case, the behavior to be encouraged is acceptance of taxes; the behavior to be changed is the extreme aversion to taxes. Taxes enable governmental policies, and the form in which they are levied is a pragmatic tool used by the government to effectuate its ends.

Given the significant uncertainty about voter preferences and the need for government to use pragmatic tools, the argument that use of a low-salience tax is undemocratic in that it does not carry out voter choices is not very robust.

148. See Cabral \& Hoxby, supra note 58, at 11 ("If a voter knows that politicians are revenuemaximizing and that they will attempt to raise taxes that are non-salient, a voter should suspect-in the absence of information-that politicians are continually increasing non-salient taxes to the extent possible without drawing attention to the increases. A sophisticated voter should assume that a politician has increased non-salient taxes unless he offers evidence to the contrary.").

149. It is also possible that if tax aversion were high enough, voters would prefer high-salience taxes. Marika Cabral and Caroline Hoxby argue that "[a] primary implication of our results is that a nonbenevolent government will wish to decrease the salience of taxes and that voters facing a nonbenevolent government will wish to keep taxes' salience high--even if the forms of taxation that are highly salient cause inconvenience and animus such as that generated by the property tax." Cabral \& Hoxby, supra note 58 , at 43.

150. There are plenty of similar examples from the nontax world, such as cherry-flavored medicine and $\$ 9.99$ price tags. 


\section{B. Low-Salience Taxes Will Make It Easier for Legislators To Adopt Higher Taxes}

This fiscal illusion, or leviathan claim, is traceable to Amilcare Puviani ${ }^{151}$ and was emphasized in the modern literature by James Buchanan. ${ }^{152}$ It is widely accepted that individuals will have imperfect information on which to base their decisions about government. The costs of obtaining this information are such that individuals are not likely to expend the resources to obtain accurate information. Buchanan and others hypothesize that citizens will systematically underestimate the cost of public goods and activities and overestimate the benefits provided and that the government will exploit this effect. The result will be a larger, less-than-optimal government. People will overconsume government services because they are unable or unwilling to obtain the necessary information to estimate the costs correctly. ${ }^{153}$

Critics give many reasons for why citizens will systematically underestimate costs, and the low salience of a tax is one of them. ${ }^{154}$ Under the leviathan hypothesis, if taxes are not easily visible, some taxpayers will freeride on the efforts of other taxpayers to reduce taxes or oppose increases. ${ }^{155}$ Another claimed distortion is that voters who misperceive their tax burden may not choose the political representatives that they might choose if they had accurate information about their representative or about political candidates.

151. James $M$. Buchanan, Public Finance IN Democratic Process: Fiscal INSTITUTIONS AND INDIVIDUAL CHOICE 131-36 (1967) (citing AMILCARE PUVIANI, TEORIA DELLA Illusione NELlE ENTRATE PUBliCHE (1897)). Puviani assumes that the government can manipulate taxes so that citizens will underestimate their tax burden by, among other things, tax-inclusive prices, disaggregation of the tax, and complex tax rules.

152. Geoffrey Brennan \& James M. Buchanan, The Power to Tax: Analytical FOUNDATIONS OF A FISCAL CONSTITUTION 13-33 (1980); BUCHANAN, supra note 151, at 126-43. The idea can be traced back to John Stuart Mill. See JOHN STUART MILL, PRINCIPLES OF POLITICAL ECONOMY WITH SOME OF THEIR APPliCations to SOCIAL PHILOSOPHY 237 (Stephen Nathanson ed., Hackett Publ'g Co. 2004) (1871) (stating that indirect taxes that are less visible than direct taxes affect government incentives).

153. Sometimes, this argument is framed as economic distortion. For example, Richard Bird and Pierre-Pascal Gendron note that there is a "hidden political benefit" to a government that imposes a VAT because revenue comes from "taxes on business inputs and is thus hidden from the consumer." Richard M. Bird \& Pierre-Pascal Gendron, Sales Taxation in Canada: The GST-HST-QST-RST "System," 63 TAX L. REV. 517, 540 (2010) ("Such hidden taxes are economically distorting, but nonetheless they often appear to be more palatable politically than visible taxes imposed on final consumers.").

154. Others include complexity, the form in which the tax is extracted, the costs, and the lack of effect the citizen would have should she attempt to act on the information.

155. Another somewhat analogous argument applies specifically to consumption taxes, which is that consumers should have "full, accurate, and clear information of the full sale prices of goods" to improve consumption choices. Confusion and overconsumption arguably decrease utility and social welfare. See Nussim, supra note 38 , at 4,7 . With respect to income taxes, the choice is the amount of public goods and activities to "consume." 
Finally, critics prefer high-salience taxes because they will impose a constraint on legislators, making it difficult to raise taxes. ${ }^{156}$

There are several problems with this argument. ${ }^{157}$ First, because lowsalience taxes are only one fiscal tool the government may use, it is difficult to know whether the use of this tool standing alone will lead to a bigger government. ${ }^{158}$ There might in fact be causality, but that is unknown. The results of empirical work on fiscal illusion generally are mixed, and there is very little empirical evidence about the relationship between salience and the size of government. ${ }^{159}$ That may be because of the difficulty in determining taxpayer perceptions about the price of public outputs. A citizen's perception of price will vary with the means used to extract the funds for government services. The more complex the system, the more difficult it will be for a citizen to form a perception. And as already noted, the more salient the information or the tax provision, the easier it will be to obtain necessary data.

156. See, e.g., Ian Ayres, A Defense of Irrational Taxation?, FrEAKONOMICs (Oct. 28, 2009, 12:42 PM), http://freakonomics.blogs.nytimes.com/2009/10/28/a-defense-of-irrational-taxation ("[A]s [a] matter of political economy, we might as a society want to keep our taxes highly salient (even if it increases the dead-weight loss of taxes) to make sure that our representatives feel more constrained when deciding whether or not to hike our rates 20 to 40 percent."); Cookson, supra note 96 ("I am not sure we should give our government officials another incentive to raise taxes."). This is closely related to the "money machine" argument that is usually raised in connection with adoption of a VAT. There is some evidence that VAT rates increase over time when they are tax-inclusive and thus less visible. See Michael Keen \& Ben Lockwood, Is the VAT a Money Machine?, 59 NAT'L TAX J. 905 (2006).

157. Galle notes that low tax salience would interfere with mechanisms used to constrain the ability of a government to raise taxes. Specifically, under leviathan-government theories, there is a competition between governments for mobile taxpayers that limits the rate at which tax increases could occur. Galle, supra note 2, at 96 . This argument is quite weak in the federal setting since taxpayer mobility is quite low (that is, leaving the country is a rarely exercised option) and for individual taxpayers, at least, there is little tax competition at the national level. See id. at 98 .

158. Becker \& Mulligan, supra note 104 (discussing factors that might affect the size of government).

159. See Brian E. Dollery \& Andrew C. Worthington, The Empirical Analysis of Fiscal Illusion, 10 J. ECON. SURVS. 261, 264 (1996) (surveying literature and concluding that results are mixed); Norman Gemmell, Oliver Morrissey \& Abuzer Pinar, Fiscal Illusion and the Demand for Government Expenditures in the UK, 15 EUR. J. POL. ECON. 687 (1999) (reviewing studies); Libor Dušek, Are Efficient Taxes Responsible for Big Government? Evidence from Tax Withholding (May 9, 2006) (unpublished manuscript), available at http://ssrn.com/abstract $=1585119$ (noting that withholding accounts for some but not all of government growth in the post-war United States). For earlier work, see Wallace E. Oates, On the Nature and Measurement of Fiscal Illusion: $A$ Survey, in TAXATION AND FISCAL FEDERALISM: ESSAYS IN HONOUR OF RUSSELl MATHEWS 65 (G. Brennan, B.S. Grewel \& P. Groenwegen eds., 1988) (surveying the literature and finding no persuasive connection between salience and government size).

McCaffery conjectures that one reason that Social Security taxes have grown over time is the fact that the burden of the employer's share of the tax falls on the employee, but this is hidden and therefore this method of raising revenue is attractive to Congress. McCaffery, supra note 40 , at 1878-80. A recent international study, however, concludes that countries that collect more of the tax from employees (more salient collection) do not spend less on public pensions than do countries that collect more from employers (less salient). Casey B. Mulligan, Ricard Gil \& Xavier X. Sala-i-Martin, Social Security and Democracy, 10 B.E. J. ECON. ANALYSIS \& POL'Y, no. 1 , art. 18 (2010), http://www.bepress.com/bejeap/vol 10/iss $1 /$ artl 18 . 
There also may be special interests at work that counteract any effect from salience. ${ }^{160}$

Second, this argument is based on the premise that citizens underestimate their taxes (and thus, receive more government than they perceive to be optimal). ${ }^{161}$ Most studies assume that individuals will undervalue low-salience taxes, that is, even if they are aware of the tax, they will assume that the amount of the tax is less than it is (zero if they are unaware of the tax). ${ }^{162}$ But it is also possible that citizens will misperceive the tax burden in the other direction; that is, they will overestimate their tax burden (or even estimate their burden correctly). We do not have conclusive empirical evidence that voters systematically underestimate their tax burden, and there is some reason to believe that they may actually overestimate. ${ }^{163}$ If individuals are aware of the tax, they may take shortcuts in estimating the tax that will result in overvaluation. 164

With respect to income taxes, even if we assume that taxpayers will not correctly calculate their tax burden, it is difficult to know whether they will underestimate or overestimate the burden. For example, some citizens may believe that everyone is subject to the top marginal rate or that everyone is subject to the estate tax. Some may confuse the tax burden with withholding.

160. Casey B. Mulligan, Don't Fear the Invisible Tax, N.Y. ECONOMLX BLoG (Apr. 21, 2010, 6:00 AM), http://economix.blogs.nytimes.com/2010/04/21/dont-fear-the-invisible-tax ("I am not especially surprised that tax visibility is empirically unrelated to the amount of taxation and government spending, because the impressions of voters who see the more visible taxes are by no means the only determinant of government spending. Special interests matter too.").

161. These assumptions about citizens' perception of taxes are probably based on the median voter to whom politicians try to appeal. The theory of the median voter predicts that policy choices will cluster in the middle and ignore extreme voter preferences. See Roger D. Congleton, The Median Voter Model, in 2 ENCYClOPEDIA OF PUBLIC CHOICE 382 (Charles K. Rowley \& Friedrich Schneider eds., 2004). Thus, we might say that we get the "correct" level of government if it is the level of government that we would get with a representative democracy, meaning that it would be like the one that incorporated the desires of the median voter. note 80 .

162. For a discussion of cognitive biases that might lead to undervaluation of taxes, see supra

163. In the Finkelstein study, electronic-toll users overestimated their tolls rather than underestimating them. Finkelstein, supra note 52, at 981. This makes it more difficult to argue that it is easier for the government to raise tolls or rates because taxpayers may believe that they are higher than they already are. In the Cabral and Hoxby study, homeowners using the tax-escrow method of paying property taxes did not systematically underestimate their taxes. Cabral \& Hoxby, supra note 58, at 2930; see also Norman Gemmell, Oliver Morrissey \& Abuzer Pinar, Tax Perceptions and Preferences over Tax Structures in the United Kingdom, 114 ECON. J. 117, 134 (2004) (showing that British taxpayers systematically overestimated income tax and VAT liabilities); Nussim, supra note 38 , at 12 (arguing that in the case of commodities, consumers, facing uncertainty, will not necessarily undervalue prices).

164. This might occur because they will round up a tax-exclusive price. For example, the current sales tax rate on purchases in New York City is $8.875 \%$. Sales and Use Tax, NYC FIN., $\mathrm{http}: / /$ www.nyc.gov/html/dof/html/business/business_tax_nys_sales.shtml (last visited Feb. 6, 2011). Those who take the sales tax into account often do not go to the trouble of actually calculating the correct amount of tax but routinely round up to add an extra $10 \%$ to purchases. There may actually be two errors. Suppose for example that the item costs $\$ 89$. The consumer may estimate the tax as $\$ 8.90$ $(10 \%)$ and then may add $\$ 9$ to the price (rounding) to get $\$ 98$ or may take $10 \%$ of $\$ 90$ (easy to calculate) to get $\$ 99$. In either case, the actual tax-inclusive price is $\$ 96.89$. 
Many are not able to accurately determine their marginal tax rate. ${ }^{165}$ Citizens may also ignore some taxes (that are not salient) and concentrate only on those that are prominent. They may also fail to take into account government benefits received that should be offset against the tax. It is also possible that the populace will systematically assume that there is a low-salience tax that they either cannot uncover or do not want to attempt to uncover. Since they do not have details about the tax, they may add some additional amount to the burden they can calculate.

Assume, for example, that voters are willing to elect those who would impose a $30 \%$ tax. Suppose that voters believe that elected officials are always going to impose a $10 \%$ low-salience tax-they just are not able to spot it. As a result, they elect officials who are committed to $20 \%$ high-salience or visible taxes. Although both voters and officials might prefer visible $30 \%$ taxes, they cannot achieve that so long as voters believe that officials will add a lowsalience $10 \%$ tax. Thus, any attempt to impose higher visibie taxes will be met with defeat because voters will believe that this will result in a tax burden higher than $30 \%$. In this case, we end up with a second-best solution that produces the right result, namely, a $20 \%$ visible tax and a $10 \%$ less visible tax that funds the level of government desired by the voters. ${ }^{166}$

Now assume that voters believe that the total taxes imposed are $40 \%$, when they prefer $30 \%$. If in fact the taxes are $30 \%$, there is a problem only if they turn the elected officials out of office based on false information. Otherwise, citizens still have their preferences about the level of government carried out. Finally, assume that voters believe that there is a $15 \%$ low-salience tax (that they cannot identify), and therefore, they pressure officials to keep high-salience taxes quite low, say at $15 \%$. (This might occur because taxpayers are so distrustful of government that they assume that it will impose a high lowsalience tax.) If the low-salience taxes are actually $10 \%$, citizens receive less government than they prefer. Under this scenario, the leviathan argument does not hold. If taxpayers overestimate their tax burden, they are extremely unlikely to receive more government than they prefer.

To the extent, however, that citizens underestimate their tax burden, it may be possible for the government to impose a higher rate of tax - and thus a higher level of government-that does not correspond to citizen preferences. Accordingly, suppose that citizens believe that total taxes imposed are only

165. See, e.g., Steven Sheffrin, Perceptions of Fairness in the Crucible of Tax Policy, in TAX PROGRESSIVITY AND INCOME INEQUALITY 309, 311-12 (Joel Slemrod ed., 1994) (reviewing the literature on this point).

166. Broadly stated, this is similar to the principal-agent story in corporate governance. Assume it is desirable to pay a fixed amount of compensation to managers. Since we know they would shirk, we might engage in monitoring or incentive compensation although each imposes additional costs. Given shirking, however, the best mix of compensation is one that would otherwise be second-best. Similarly, while it would be better to impose only high-salience taxes, if the populace believes that there might be low-salience provisions, a mix is a second-best solution. 
$20 \%$ when actual taxes are $30 \%$. This may be because they are unable to accurately assess tax rates or because they are unaware of a $10 \%$ low-salience tax. This creates an opportunity for the government to propose a $10 \% \operatorname{tax}$ increase without opposition because taxpayers will believe that it will fund a government at their preferred $30 \%$ level. And that would produce a larger government than voters prefer. But this would be true only if voters systematically underestimated their taxes-a fact that has not been proven.

It is possible that there is a subset of voters that prefers higher taxes, perhaps because they favor goods and services provided by a large government or perhaps because they favor significant redistribution. Hiding taxes does nothing to win the support of those voters. While this might seem to defeat the use of low-salience taxes, such taxpayers would appear to be the exception rather than the rule.

\section{Debiasing}

A third objection to the use of low-salience tax provisions is based on the possibility of debiasing. An individual who incurs an economic cost as a result of a bias (for example, ignorance or intentionally ignoring a tax) has an incentive to debias herself--that is, to obtain or stop ignoring information about the tax provision. Given that low-salience taxes are not actually hidden, taxpayers have a good source of information. If individuals routinely debiased, the use of low-salience taxes as a fiscal policy tool would produce a short-term advantage at best.

This critique is valid only to the extent we believe that debiasing would actually occur. But there are several reasons to believe that debiasing is not likely. First, taxpayers have to be aware that they are making a cognitive error-this depends on feedback, which might come from other taxpayers or perhaps from politicians. In order for feedback to come from other taxpayers, there must be some group that does not ignore low-salience provisions and understands their effect. That is mostly like to be experts or perhaps highincome taxpayers who bear a larger tax burden. History tells us that experts largely have been ineffective in capturing public attention. They will have little effect unless they grab the imagination of the general populace. High-income taxpayers do not have much incentive to provide feedback to others who fail to take low-salience taxes into account. While it is theoretically possible for one political group or policy entrepreneurs to provide information to voters in order to gain political advantage, at the federal level that is less likely because both parties benefit from the increased revenue from low-salience taxes. Even if one political group chose to "disclose" low-salience taxes, it is entirely possible that it would not be believed or that voters would not care.

Generally, individuals shed themselves of cognitive bias through education. But acquiring and understanding information about public finance and various taxes is problematic and costly. The details of taxation are 
inordinately complex and, most would say, quite boring and incomprehensible. It would take a significant, time-consuming campaign to educate individuals sufficiently about taxation so that they would focus on less prominent taxes or tax provisions. And the payoff is quite low. For most citizens, the change in taxes levied would be small. And if low-salience provisions are repealed, legislators may adopt high-salience taxes in their place. Another possibility is that debiasing may come from experience. Laboratory studies show that where individuals play a game repeatedly, their cognitive biases decrease over time. ${ }^{167}$ But there is doubt that these results could be replicated in the real world of taxes where experience with taxes is sporadic and for many only an annual event. Furthermore, if a tax provision is so low-salience that taxpayers are unaware of it, their "experience" with it will be quite limited.

There is a further problem in how debiased citizens express their newfound dislike of low-salience taxes. The most direct means is a vote in a congressional election, but this issue is likely to be swamped by other more salient and pressing issues. ${ }^{168}$ Finally, low-salience taxes are not invisible, and information about them is available. If taxpayers are choosing to ignore such taxes, that may reflect their preference. If so, they may not have an incentive to debias.

For all these reasons, the likelihood of debiasing is quite low, and thus, the argument that the use of low-salience taxes would be ineffective is not convincing.

\section{Distributional Concerns}

Another potential problem is that low-salience taxes may be regressive. ${ }^{169}$ Taxpayers who are simply ignorant of a tax (or a tax feature) may be lower income because wealthier individuals either are better educated or can pay someone to look out for their interests. Thus, it is less likely that a tax provision would completely escape the notice of a well-to-do individual. If so, legislators may find low-salience taxes more effective with low-income individuals than with high-income individuals.

Is the distributional concern that Congress will fool only low-income taxpayers and therefore that low-income taxpayers will bear a larger-thandesirable tax burden? The answer to that question is unknown. Very little is known about heterogeneity (with respect to income) and cognitive bias because

167. See Sausgruber \& Tyran, supra note 59.

168. For arguments as to why debiasing may not occur, see Galle, supra note 2, at 89-93; and McCaffery \& Baron, supra note 11, at 1785-86. The latter authors' experiments showed little effect from individual education. Id.

169. See Galle, supra note 2 , at 100. 
the literature is quite nascent. ${ }^{170}$ The conclusion that low-income taxpayers pay less attention to all low-salience taxes is far from robust, and the evidence that exists cuts both ways. Although one might expect low-income taxpayers to be more attentive to low-salience taxes because of their budget constraint, there is some evidence that, with respect to the purchase of certain consumer goods, they are not. ${ }^{171}$ High-income individuals may be more likely to ignore a tax (even if it is known) because the disutility of computing a tax is larger than the subjective present value of the tax. In that case, low-salience taxes may actually affect high-income taxpayers more than low-income taxpayers. One reason this might be so is that high-income taxpayers have higher opportunity costs. While this is likely to be true with commodity taxes, it is less plausible with respect to a broad-based tax where the present value of the tax would have to be quite low to be less than the disutility of calculating the tax. As compared to commodity taxes, the income tax would (or could be) significant; furthermore, the disutility of making calculations would decrease with wealth, assuming wealth correlates with tax burden.

It also does not follow that all low-salience taxes must be regressive. For example, Social Security, viewed as a low-salience tax because its incidence is not understood, is indeed regressive. But other low-salience income tax provisions like the AMT and the PEP and Pease provisions are targeted solely at high-income taxpayers.

Another potential distributional concern is that the tax system will be less progressive (or regressive) than citizens actually prefer. If a tax is ignored, citizens will be unaware of its characteristics, including the degree of progressivity. For example, most voters would be unaware of the degree of redistribution attributable to the corporate tax because of its low salience and thus would have a misperception about the extent of progressivity in the system. $^{172}$

On the other hand, low-salience taxes may increase progressivity in a way that is politically acceptable. One could imagine that a direct monetary transfer from the wealthy to the poor might not be palatable even to those who favored a good deal of redistribution, but it might be accomplished via phase-outs or the AMT. Of course, it is possible that low-salience taxes could result in too much redistribution, meaning that there is more distribution than citizens in the abstract would choose. Because the redistribution is not visible, they would not object.

170. See Jacob Goldin \& Tatiana Homonoff, Smoke Gets in Your Eyes: Cigarette Tax Salience and Regressivity 2 (Princeton Univ. Indus. Relations Section, Working Paper No. 561, 2010), available at http://www.irs.princeton.edu/pubs/pdfs/561.pdf.

171. See id. at 30-31 (showing that attentiveness to sales taxes on cigarettes imposed at the register declines with income but noting that this pattern may not hold for all goods).

172. This potential equity problem could be due to other cognitive biases, as well as salience. See McCaffery \& Baron, supra note 11, at 1781-82 (noting that "psychologically pleasing taxes" such as the corporate income tax generally are not as progressive as people perceive them to be). 
In sum, there are three possibilities: low-salience taxes may result in less redistribution than citizens prefer, may result in more redistribution than they prefer, or may help to achieve politically the preferred distribution. Without more empirical work, it is difficult to be sure which predominates.

\section{E. Ineptness}

Several final concerns suggest a practical rather than a normative critique, that is, that the use of low-salience provisions simply will not work. One concern is that legislators will not be able to use a cognitive bias carefully in designing a tax or provision. If they are not able to do this well, then perhaps it would be better if they did not do it at all. Another charge is that exploiting salience will not work as a fiscal tool because anti-tax forces will expose the low-salience provision. And, finally, taxpayers may object to being manipulated. ${ }^{173}$

While each concern has some validity, none is powerful enough to rule out the use of low-salience provisions in tax design. The fact that legislators on occasion may do a poor job of using a particular tool does not justify eliminating that approach from its fiscal toolkit. The best response to the final two charges is that taxpayers may prefer low-salience provisions and would not consider themselves manipulated even if the design were pointed out to them. While individuals may have a general aversion to being manipulated, the current use of low-salience provisions suggests that they are not viewed as exploitative. There are numerous examples of low-salience provisions that currently exist that have been exposed to sunlight, and yet, Congress retains them. That may be because it is only the cognoscenti who recognize their effect, while average taxpayers are either unaware of them or their consequences. Or they may continue to exist because everyone wants them to exist. That is, both Congress and taxpayers recognize the need for taxes and prefer them in this form-Congress because it is less likely to be punished, and taxpayers because low-salience taxes are less painful.

\section{An Example of Appropriate Use}

This Part lays out a specific example of when it would be appropriate for Congress to exploit the salience bias. When the politics of taxation are such that it is impossible for Congress to raise tax rates directly and additional revenue is warranted, it is appropriate for Congress to intentionally adopt low-salience features of an income tax. This Part briefly explores the current political economy of tax legislation that makes the straightforward adoption of tax legislation-particularly changes in tax rates and increases in tax revenues-

173. This last concern depends on taxpayers understanding the impact of low-salience taxes. As suggested above, that requires both debiasing and a rejection of the process once it is understood. 
extremely difficult even in a period of high (and rising) deficits. Taxes with low salience are one useful fiscal tool for overcoming these political-economy problems. This Part suggests that low-salience tax provisions may be a way to get past the "no new taxes" rhetoric that has plagued public discourse about taxes for the last several decades and that ultimately has hamstrung Congress. There are three components of this argument: tax aversion, budget deficits, and the politics of taxation.

\section{A. Tax Aversion}

The political-economy story depends in part on the public's dislike of taxes. A growing literature has considered the concept of "tax aversion" as something distinct from loss aversion. ${ }^{174}$ The notion is that the disutility from paying taxes is greater than that from other types of losses. ${ }^{175}$ The core idea is that calling something a tax rather than something else (for example, a fee or mandated payment) creates a negative reaction. ${ }^{176}$ While most of the work has focused on how this might increase tax avoidance and evasion, ${ }^{177}$ and therefore, affect compliance, this disutility likely also manifests itself by affecting Congress's ability to raise revenue. Thus, we start from the proposition that although citizens desire the public goods (and perhaps redistribution) provided by the government, it will be difficult to extract the revenue needed to pay for public goods.

174. McCaffery, supra note 40, at 1878 (defining tax aversion as "a phenomenon . . akin to but distinct from loss aversion, whereby individuals attach disproportionate disutility to government extractions perceived or labeled as 'taxes"').

175. See Fennell \& Fennell, supra note 11, at 79 (defining one kind of tax aversion as "the amount by which one's aversion to a tax exceeds the economic cost of the tax"). It is not hard to locate undocumented statements that Americans hate taxes-it is a given requiring no support. See, e.g., McCaffery \& Baron, supra note 37, at 289 ("People do not like to pay taxes."); Joshua D. Rosenberg, The Psychology of Taxes: Why They Drive Us Crazy and How We Can Make Them Sane, 16 VA. TAX REV. 155, 157-58 (1996) ("Most working Americans would readily acknowledge that taxes drive them crazy. . . . [O]nly tax laws seem capable of engendering nearly universal anger, anxiety, paranoia and outright hatred, as well as substantial noncompliance. . . For most Americans, any tax is a bad $\operatorname{tax} . . .$.$) .$

176. McCaffery \& Baron, supra note 81 , at $117-18$ (finding that labeling something as a tax is likely to make it less preferable than, for example, labeling it as a fee). McCaffery and Baron conducted a number of experiments in which subjects evaluated payment mechanisms for various government programs. They found that labels matter and the subjects generally reacted negatively to new taxes. McCaffery \& Baron, supra note 11, at 1759-61. In another experiment, Catherine Eckel, Philip Grossman, and Rachel Johnston also found that reactions were different to a payment labeled as a tax as compared to an unlabeled payment. Participants who were told that the sum of money they had been given had been subject to a tax tended to reduce their voluntary contributions to charity to offset the tax. Catherine C. Eckel, Philip J. Grossman \& Rachel M. Johnston, An Experimental Test of the Crowding Out Hypothesis, 89 J. PUB. ECON. 1543 (2005).

177. See, e.g., McCaffery \& Baron, supra note 81 , at 117-18. 


\section{B. The Budget Crisis}

A second component of the instrumentalist argument is that Congress needs to raise revenue. The unsustainable trajectory of the U.S. budget is well known. ${ }^{178}$ Federal debt held by the public could surpass its previous highest level- $109 \%$ of GDP - by $2020 .^{179}$ The Congressional Budget Office estimates that expenditures on Social Security, Medicare, Medicaid, the Children's Health Insurance program, and health-insurance subsidies provided through soon-to-be-established insurance exchanges will constitute $16 \%$ of GDP in $2036 .{ }^{180}$ If current law remains in force, in thirty years, government revenues are expected to meet only two-thirds of all expected expenditures in $2080 .^{181} \mathrm{It}$ is widely agreed that this is a crisis that cannot be ignored forever. ${ }^{182}$ Growing budget deficits will result in rising interest rates that discourage investment in the United States and ultimately will cause economic disruptions. ${ }^{183}$ It is also understood that there are only two solutions: cutting spending and raising revenue. To date, despite rhetoric about the need to cut spending programs, neither Congress nor the public has shown much taste for doing so. Cutting "government waste" would make only a small dent in the problem; large-scale cuts in Social Security and Medicare would be required, and that may be politically implausible. Thus, the United States faces the need for significant additional revenue that must be raised from a populace with an aversion to taxes.

\section{Political Rhetoric and the Impossibility of Raising Taxes Directly}

Congress has 'altered the rate structure of the income tax in the past, usually when substantial amounts of additional revenue were needed, and often

178. See, e.g., The Long-Term Budget Outlook and Options for Slowing the Growth of Health Care Costs: Hearing Before the S. Comm. on Fin., 110 th Cong. 1 (2008) (statement of Peter R. Orszag, Director, Congressional Budget Office), available at http://www.cbo.gov/ftpdocs/93xx/doc9385/06-17LTBO_Testimony.pdf ("[U]nder any plausible scenario, the federal budget is on an unsustainable path.").

179. U.S. GOV'T ACCOUNTABILITY OFFICE, GAO-10-468SP, THE FEDERAL GOVERNMENT'S LONG-TERM FISCAL OUTLOOK, JAN. 2010 UPDATE 1 (2010), available at http://www.gao.gov/new.items/d10468sp.pdf.

180. CONG. Budget OfFICE, REDUCING THE DEFICIT: SPENDING AND REVENUE OPTIONS 3 (2011), available at http://www.cbo.gov/ftpdocs/120xx/docl2085/03-10-ReducingTheDeficit.pdf.

181. FIN. MGMT. SERV., U.S. TREASURY DEP'T, FINANCIAL REPORT OF THE U.S. GOVERNMENT, 2009-MANAGEMENT'S DISCUSSION AND ANALYSIS 23 chart J, available at http://www.gao.gov/financial/fy2009/09mda.pdf.

182. See, e.g., David A. Stockman, The Bipartisan March to Fiscal Madness, N.Y. TIMES, Apr. 24, 2011, at A22.

183. See, e.g., Economic Outlook: Hearing Before the Joint Econ. Comm., 109th Cong. (2005) (statement of Alan Greenspan, Chairman, Federal Reserve Board), available at http:/www.federalreserve.gov/BOARDDOCS/TESTIMONY/2005/20051103/default.htm; Alan J. Auerbach, Jason Furman \& William G. Gale, Facing the Music: The Fiscal Outlook at the End of the Bush Administration, 119 TAX NOTES 981 (2008). 
in ways that were direct and salient. ${ }^{184}$ But in the last several decades, Congress has found it difficult to increases rates or to expand the base in a salient way. Indeed, the public's aversion to taxes has been exploited so much that it has become almost impossible to raise taxes directly. There are several reasons for this, which this Section briefly catalogues.

\section{Interest Group Politics Predicts That Congress Will Not Support Raising Taxes Directly}

The dominant and standard view of politics for the last several decades has been public-choice theory, which usually is taken to mean interest group politics. ${ }^{185}$ That approach treats the government as an actor in what is essentially a market transaction, providing goods and services (via legislation) to interest groups that want to maximize the income of their members. ${ }^{186}$ Interest groups bid for legislation and pay for it with campaign contributions, votes in elections, and the like. ${ }^{187}$

The originator of this approach, Mancur Olson, argued that two conditions could predict when effective interest groups would emerge and the policies that they prefer. The first is that the groups must be small. Although every member of a group stands to benefit from the results obtained, formation and coordination costs are high, and they increase as the group grows in size. The second is the existence of free-riders. The desired legislation may affect a significantly larger group, and this creates an incentive to free-ride. Smaller groups lessen the coordination problem,-and narrower policy objectives lessen the free-rider problem. Thus, one would expect to see small groups who will gain a lot from very narrow objectives controlling legislation.

184. During World War I, rates were increased to fund war expenditures. Rates were subsequently decreased in the 1920s. Anne L. Alstott \& Ben Novick, War, Taxes, and Income Redistribution in the Twenties: The 1924 Veterans' Bonus and the Defeat of the Mellon Plan, 59 TAX L. REV. 373, 375 (2006) (noting that tax rates increased from 7\% in 1915 to $77 \%$ in 1918, and then decreased to $25 \%$ in 1926). Tax rates rose during the Depression under Hoover and Roosevelt. In the decades after World War II, top marginal rates declined dramatically, from $94 \%$ in 1945 to $28 \%$ in 1988 . U.S. Federal Individual Income Tax Rates History, 1913-2011, TAX FoUND., http://www.tax foundation.org/publications/show/151.html (last updated Mar. 23, 2011).

185. Little attention was paid to tax legislation during the heyday of public-interest theory. Under this approach, the government is assumed to be motivated to improve general welfare by financing public goods and correcting for market failure. Those who hew to this explanation emphasize ideology-legislators have a desire to enact good policy that will improve society. No one seems to have ever suggested that tax legislation could be completely explained by public-interest theory. This approach was subject to a good deal of criticism and ultimately was questioned in the academic literature.

186. This approach is traced to Mancur Olson and has remained prominent. See MaNCUR OLSON, THE LOGIC OF COLLECTIVE ACTION (1965).

187. See, e.g., Jonathan R. Macey, Promoting Public-Regarding Legislation Through Statutory Interpretation: An Interest Group Model, 86 COLUM. L. REV. 223 (1986). Public-choice theory is not without its critics. See, e.g., Steven Kelman, Why Public Ideas Matter, in THE PowER OF PUBLIC IDEAS 31 (Robert B. Reich ed., 1988); Cass Sunstein, Interest Groups in American Public Law, 38 STAN. L. REV. 29, $48-49$ (1985). 
In the tax area, there is a fairly long history of examining interest group politics. ${ }^{188}$ There have been several prominent attempts to explain tax legislation from a public-choice perspective. Richard Doernberg and Fred McChesney have argued that the increasing rate of federal tax legislation that proved to be unstable could be explained by Congress's responding to wellorganized groups who paid for benefits that maximized their wealth. ${ }^{189}$ They contend that business groups that lobby to obtain tax favors for themselves or their constituents are the primary "public" participants in the tax legislative process, in which tax legislation is delivered to the highest bidder. ${ }^{190}$ These groups are interested in only short-term contracts rather than long-term deals because there is a turnover in the players on Capitol Hill. Politicians are also more interested in short-term deals because they can extract more benefit each time the process begins. ${ }^{191}$ Standard public-choice theory posits that public interest or public opposition to interest groups will be diffuse and ineffective. In the tax arena, that opposition historically has come from the Treasury Department, the Joint Committee on Taxation, and certain public-interest tax lobbying organizations. These groups, however, have been largely ineffective.

Another version of public-choice theory is that developed by Edward McCaffery and Linda Cohen, which they dub "ex ante rent extraction." 192 McCaffery and Cohen concede that interest group politics plays a major role in the development of legislation, but they argue that it cannot explain all tax legislation. Under this approach, because Congress is addicted to the money received in the form of campaign contributions, it creates special-interest groups from which it hopes to subsequently extract contributions. The difference between this mode of analysis and standard interest group analysis is that the politicians themselves solve the coordination problems. The politicians who are "rent-extracting" precede the interest groups that are "rent-seeking."

188. See, e.g., JEFFrey H. BIRnBaUm \& Alan S. Murray, Showdown at GuCCi GUlCh: LAWMAKERS, LOBBYISTS, AND THE UNLIKELY TRIUMPH OF TAX REFORM (1987); TIMOTHY J. CONLAN, MARgaret T. WRIGHTSON \& DAVID R. BEAM, TAXING CHOICES: THE POLITICS OF TAX REFORM (1990) (analyzing the processes behind the passage of the Tax Reform Act of 1986); THOMAS J. REESE, THE POLITICS OF TAXATION (1980) (explaining the difficulty in passing meaningful tax-reform legislation); William L. Cary, Pressure Groups and the Revenue Code: A Requiem in Honor of the Departing Uniformity of the Tax Laws, 68 HARV. L. REV. 745, 747-73 (1955) (identifying sources of pressure on Congress to create special tax rules); Rebecca M. Kysar, The Sun Also Rises: The Political Economy of Sunset Provisions in the Tax Code, 40 GA. L. REV. 335 (2006) (discussing how interest groups use sunset provisions to extract rent); Stanley S. Surrey, The Congress and the Tax LobbyistHow Special Tax Provisions Get Enacted, 70 HARV. L. REV. 1145, 1149-81 (1957) (attempting to enumerate reasons that tax lobbyists seek "loopholes").

189. Richard Doernberg \& Fred McChesney, Doing Good or Doing Well?: Congress and the Tax Reform Act of 1986, 62 N.Y.U. L. REV. 891 (1987) [hereinafter Doernberg \& McChesney, Doing Good]; Richard Doernberg \& Fred McChesney, On the Accelerating Rate and Decreasing Durability of Tax Reform, 71 MINN. L. REv. 913, 926 (1987) [hereinafter Doernberg \& McChesney, Accelerating Rate].

190. Doernberg \& McChesney, Doing Good, supra note 189, at 897-98.

191. Doernberg \& McChesney, Accelerating Rate, supra note 189, at 946-54.

192. Edward J. McCaffery \& Linda R. Cohen, Shakedown at Gucci Gulch: The New Logic of Collective Action, 84 N.C. L. REV. 1159 (2006). 
The politicians focus on tax provisions that apply to very few people who face high stakes. In a sense, they threaten to eliminate the rent by imposing higher taxes or eliminating a tax incentive. This is most effective when the group affected has the ability to organize and be politically effective. ${ }^{193}$

Interest group politics is a very robust explanation for the incremental nature of the overwhelming majority of tax legislation. Almost all provisions in tax legislation are incremental changes to the law as it exists, and most benefit specific interest groups, usually business. ${ }^{194}$ There is no reason to believe that interest groups have lost any power over the last two decades, nor is there any reason to believe that legislators are less interested in rent-extraction. In fact, the reverse is true. A number of factors make it likely that interest group politics will continue to control the political agenda and will be a barrier to rate increases and raising revenue.

Both the rent-seeking and the rent-extraction models predict that small groups with high stakes will emerge to control legislation, specifically legislation with concentrated specific benefits and costs to the groups. Conversely, groups will have less interest in legislation with diffuse benefits and significant costs. One implication is that special-interest groups largely will have no interest in general tax rate increases due to both coordination problems and free-riding. While there may be particular aspects of rate changes (for example, changes to the corporate tax rate) that might cause interest groups to form, general rate changes are not likely to spark the formation of such groups. Rate changes present the classic example of free-riding since almost everyone will be affected.

Setting rates is therefore a ballot-box issue, and neither rent-seeking interest groups nor rent-extracting politicians are interested in ballot-box issues. The rent-extraction model would predict that Congress would avoid a ballotbox issue, that is, one that is likely to appeal to voters generally, particularly

193. McCaffery and Cohen list five properties of rent-extraction: (1) the issue will be one of high stakes to a small group with a narrow policy focus that matters to the group; (2) the issue will not be of much importance to most voters and therefore is not likely to be that important in election politics; (3) the issue will be two-sided, that is, groups on both sides will be willing to pay so that legislators can gain no matter what their position is; (4) there must be plausible action that Congress can undertake; and (5) the issue will be such that the legislation will be reasonably long-lived so that Congress cannot immediately undo it, thus negating an incentive for interest groups to pay. Id. at 1177-78. One result, according to McCaffery and Cohen, is that there is little incentive to actually solve the problem since stringing along all the interest groups creates more opportunities for them to pay. Id. at 1179 . For an example applying the rent-extraction model, see Kysar, supra note 188.

194. See David R. Beam, Timothy J. Conlan \& Margaret T. Wrightson, Solving the Riddle of Tax Reform: Party Competition and the Politics of Ideas, 105 POL. SCl. Q. 202 (1990). Interest group politics does not, however, explain all incremental tax legislation. There are some (although not many) examples that do not seem to be in response to rent-extraction. For example, the legislation that created a uniform definition of "child" across various sections of the Tax Code, see Working Families Tax Relief Act of 2004, Pub. L. No. 108-311, $\$ \$ 201-207,118$ Stat. 1166, 1169-78 (codified in scattered sections of 26 U.S.C.), as well as two major simplification efforts, the Installment Sales Revision Act, Pub. L. No. $96-471,94$ Stat. 2247 (1980) (codified as amended in scattered sections of 26 U.S.C.), and the Subchapter S Simplification Act, Pub. L. No. 97-354, 96 Stat. 1669 (1982) (codified as amended in scattered sections of 26 U.S.C.), were targeted quite broadly. 
during elections. On the surface, this seems incorrect. The evidence is that politicians devote a good deal of attention to taxes in election years. Presidential candidates often include comments about the tax system in their standard stump speeches, and reform of the tax system is a perennial question in presidential debates (but increasing taxes and facing the budget crisis are generally off the table). ${ }^{195}$ Although legislators also talk about taxes in election campaigns, interest group politics helps to explain why in fact they do not act on their expressed concern. Furthermore, many congressional politicians are no longer concerned about reelection-they are assured of retaining their seats. ${ }^{196}$ Thus, there is little need to move on a ballot-box issue.

The ex ante rent-extraction model predicts that payments to politicians might occur simply to maintain the status quo. ${ }^{197}$ Increasing taxes upsets the status quo. While there might be winners, it is highly unlikely that they would be interest groups. There are few ways for Congress to extract money out of rate changes; thus it has very little interest in doing so. On the other hand, it is relatively simple for Congress to extract money in order to keep the status quo. Accordingly, legislators have an interest in floating specific proposals that, in keeping with the rent-extraction model, might attract small groups facing large stakes. Public-choice theory suggests that interest groups prefer repeat opportunities to bargain and legislators also prefer recurring opportunities to extract rent. Therefore, those interest groups who are in fact lobbying for tangible benefits for their members are likely not to be interested in rate changes that might block future opportunities for bargaining.

In sum, the standard view of politics predicts that raising taxes-a ballotbox issue-will be of little interest to political actors.

\section{Institutional Barriers Predict That Congress Will Not Support Increasing Taxes Directly}

There are a number of institutional barriers that make it exceedingly difficult to reach a consensus on raising marginal tax rates or raising revenue. Our Madisonian system of checks and balances builds in a need for support from both the executive and legislative branches. Traditionally, the political obstacles are overcome on rare occasions when a very strong president is elected with party majorities in both houses of Congress. The president then shapes public opinion to support legislative reform. This is usually what has

195. See Seema Mehta \& Stuart Silverstein, Obama Courts Middle-Class Virginians with Tax Strategy, L.A. TIMES, Aug. 21, 2008, at Al1 (reporting that then-presidential candidate Barack Obama had proposed "a $\$ 1,000$ tax break for most wage earners"); Tom Redburn, Huckabee Sales Tax Plan Appeals, But Is It Fair?, N.Y. TIMES, Jan. 6, 2008, at A16 (assessing Republican presidential candidate Mike Huckabee's tax-reform proposal to replace the federal income and payroll taxes with a national sales tax).

196. See Ctr. for Responsive Politics, Reelection Rates over the Years, OPENSECRETS.ORG, http://www.opensecrets.org/bigpicture/reelect.php (last visited Feb. 7, 2011).

197. McCaffery \& Cohen, supra note 192, at 1174. 
happened when anything that could be construed as tax reform occurs. ${ }^{198}$ But shifts in party politics and the role of congressional leaders have changed this dynamic.

George Yin argues that over the last several decades there has been a strengthening of the party system and a corresponding decrease in committee leadership, especially in the House. ${ }^{199}$ A number of events have created this situation. They include the repeal of the automatic seniority system for choosing the committee chairs, as well as curtailment of the chair's power and reduction in committee staffs. ${ }^{200}$ At the same time, the party assumed more control over legislation, including setting the agenda and providing language. ${ }^{201}$ While this was happening on the Hill, historically neutral tax policy advisors in the Treasury Department became less important as tax policy analysis shifted to the political office in the White House. ${ }^{202}$ Yin argues that the effect on tax legislation is ambiguous. A top-down organizational structure can offset the possibility that various committees acting independently can produce legislation that is not favored by anyone. Party leaders can require committees to commit to support legislation favored by the party. If the party has no interest in raising rates, the committees will not either. ${ }^{203}$ Also contributing to the lack of interest in real tax policy, Yin argues, is the loss of specialization benefits provided by strong committees and the decline in the committee's ability to provide good information. This factor is important, however, only if the parties are not interested in tax increases. ${ }^{204}$ The political party has been more important for a long time, and neither party has shown much interest in the budget crisis or in additional sources of revenue.

Another aspect of this is the "Permanent Campaign." 205 The necessity for Congress to be constantly involved in a reelection campaign that requires huge amounts of fundraising has resulted in an external focus that does not permit time for "working as a deliberate and collaborative body" for the public good. ${ }^{206}$ The economics of campaign financing are such that House members must spend a great deal of time raising money, usually far away from

198. See Susan B. Hansen, The Polttics of Taxation: Revenue Without REPRESENTATION 62 (1983) ("[M]ajor tax innovations show strong links to periods of political realignment and social crisis, in marked contrast to the incremental policies characteristic of 'normal' politics.").

199. George K. Yin, Is the Tax System Beyond Reform?, 58 FLA. L. REV. 977, 1019 (2006).

200. Id. at $1019-20$

201. Id. at 1021 .

202. Id. at 1024

203. Id. at 1033 .

204. Id. at 1036-37.

205. See The Permanent Campaign and Its Future (Norman J. Ornstein \& Thomas E. Mann eds., 2000). The book's thesis is essentially that there is no longer any distinction between governance and campaigning.

206. See Y in, supra note 199 , at 1025 . 
Washington. ${ }^{207}$ Because members are often in very safe seats, they are not worried about ballot-box issues, particularly issues that might actually cost votes. Instead, they are most interested in raising money. The huge amount of time that must be focused on fundraising and campaigning during the Permanent Campaign makes it difficult to mount a huge and potentially unpopular undertaking such as solving the budget crisis. There is time only for symbolic efforts. ${ }^{208}$

Another institutional factor is budget rules, specifically pay-as-you-go ("PAYGO") budget rules. Budget policy is no longer exogenous to tax policy, and there are features of budget policy that make significant changes to the tax system quite difficult. When Congress operates under PAYGO rules, any legislation to lower revenues or expand entitlement spending-relative to current law projections (that is, the "baseline")-must be offset with corresponding revenue increases or spending cuts. However, unlike the statutory PAYGO rules that expired several years ago, which required sequestration by the executive branch if they were violated, ${ }^{209}$ the current rules are internal rules that Congress must choose to enforce and can waive by a supermajority vote. ${ }^{210}$ The fact that Congress recently approved an AMT patch without providing for revenue offsets ${ }^{211}$ is evidence that PAYGO rules may not be a strong barrier. Even in the absence of the PAYGO rules, Congress has often acted with a revenue-neutrality constraint. Both Treasury $\mathrm{I}^{212}$ and the recent tax reform panel ${ }^{213}$ also operated under a revenue-neutrality constraint, that is, reform must raise no more and no less than current revenue raised by the income tax. While it would appear that the need for revenue neutrality would make it easier for Congress to raise tax rates directly to offset spending proposals, in practice Congress has had to resort to indirect means.

207. See Daniel Shaviro, Beyond Public Choice and Public Interest: $A$ Study of the Legislative Process as Illustrated by Tax Legislation in the 1980s, 130 U. PA. L. REV. 1, 87 (1990) (discussing the effects of campaign financing).

208. See Yin, supra note 199 , at 1029 . Yin cites the perennial introduction of the Tax Code Termination bill as an example of the lack of seriousness with which Congress addresses significant policy issues. The bill would repeal the entire code, to be followed by an unspecified simple and fair tax. Id. at 1029 \& n. 203.

209. Budget Enforcement Act, Pub. L. No. 101-508, tit. XIII, $\S 13101,104$ Stat. 1388-573, 1388-575 to 1388-577 (1990) (codified as amended in scattered sections of 2 \& 15 U.S.C.).

210. Statutory Pay-As-You-Go Act of 2010, Pub. L. No. 111-139, tit. I, 124 Stat. 8.

211. American Recovery and Reinvestment Tax Act of 2009, Pub. L. No. 11-5, tit. I, §§ $1011-$ 1012, 123 Stat. 115, 319.

212. U.S. DEP'T OF THE TREASURY, TAX REFORM FOR FAIRNESS, SIMPLICITY, AND ECONOMIC GROWTH 14 (1984), available at http://www.treasury.gov/resource-center/tax-policy/Pages/tax-reformindex.aspx.

213. See President's AdVISORY PaNel on Fed. TAX Reform, Simple, Fair, ANd PRoGROWTH: PROPOSALS TO FIX AMERICA'S TAX SYSTEM 42 (2005), available at http://www.taxpolicycenter.org/taxtopics/upload/tax-panel-2.pdf. 


\section{Mitigating Factors That Might Result in Raising Taxes Directly Are Not Likely To Occur}

There are different forms of politics that might create a setting in which tax increases would be considered, but those forms are either not present or lead to the opposite conclusion. David Beam, Timothy Conlan, and Margaret Wrightson argue that one important form is the "politics of ideas.".214 Four factors might push interest group politics to the side. The first is the concept that ideas are an independent and influential force in politics. The key difference between the politics of ideas and interest group politics is that individuals will not necessarily act in their own self-interest-at least, not in their own economic self-interest. ${ }^{215}$ The second factor is that the power of ideas is expressed in symbolism or in public-relations values. Third, experts will play a major role. As David Bradford has noted, "experts inevitably shape the crucial details of economic regulatory systems." "216 The fourth factor is the role played by policy entrepreneurs (individuals "who assemble[] the key ingredients essential for government action"). ${ }^{217}$ Daniel Shaviro also cites the rise of policy entrepreneurship as one factor that offsets a narrow reading of interest group politics as the only explanatory fact. By policy entrepreneurship, he means "the investment of personal resources in promoting a particular policy, with the anticipated 'return' often depending on the enactment of legislation."218

While to some extent there has been a politics of ideas with respect to taxes for the last decade, that idea has largely been the demonization of taxes and the need to keep rates low. Symbolism and public relations with regard to taxes have occurred, but they have pushed in the other direction. Although think tanks and other policy entrepreneurs have attempted to educate the public about budget unsustainability and have offered proposals to tame the budget, ${ }^{219}$

214. Beam et al., supra note 194, at 202-08; see also Shaviro, supra note 207, at 98 (noting that ideas matter a great deal-politicians pursue ideological ends and ideas sway people en masse).

215. Beam et al., supra note 194, at 203-04 (contrasting the politics-of-ideas approach and interest group politics).

216. David F. Bradford, Tax Reform: Waiting for a New Consensus of the Experts, 79 TAX NOTES 899,899 (1998).

217. CONLAN ET AL., supra note 188, at 247 ("[Entrepreneurs] act as middlemen between professional experts, who formulate and perfect policy solutions, and the broader political arena. Entrepreneurs simplify and distill those complex ideas and then link them to values that are accepted by and are familiar to the broader public.").

218. Shaviro, supra note 207, at 93-94.

219. See, e.g., Pete Domenici \& Alice Rivlin, Bipartisan Policy CTr., Restoring AMERICA'S FUTURE: REVIVING THE ECONOMY, CUTTING SPENDING AND DEBT, AND CREATING A SIMPLE, PRO-GROWTH TAX SYSTEM (2010), available at http://www.bipartisanpolicy.org/sites/default/files/BPC\%20FINAL\%20REPORT\%20FOR\%20PRINTE R\%2002\%2028\%2011.pdf; FISCAL ROADMAP PROJECT, COMM. FOR RESPONSIBLE FED. BUDGET, A PREVENTABLE CRISIS: EXPLORING FISCAL CRISIS SCENARIOS FOR THE UNITED STATES (2010), available at http://crfb.org/document/preventable-crisis-exploring-fiscal-crisis-scenarios-united-states; Maya MacGuineas, Creating a Fiscal Turnaround in the United States, COMM. FOR RESPONSIBLE FED. 
none seems to have caught the public imagination. Notably, few policy entrepreneurs have cropped up in Congress. To some extent, this must be attributed to the weakness of congressional leaders. Shaviro notes that congressional leaders have "stronger prestige and ideological incentives than rank and file members" and "tend to be less subject to interest group influence." 220 When congressional leaders control the legislative process, interest groups are less likely to influence legislation. This creates the opportunity for policy entrepreneurs among the leadership. If that leadership were interested in raising revenue, they would have an opportunity to move it to the legislative agenda. But congressional leadership today is not nearly as strong as it previously was. One takeaway from this evolution is that interest group politics becomes more important. Another takeaway is that this congressional leadership has been displaced by party control. The rise in the power of the party has also been accompanied by interparty polarization. The last decade has witnessed virtually no bipartisan efforts in Congress. ${ }^{221}$ And yet, a bipartisan effort will be necessary to tackle the budget crisis.

What about the possibility of external pressure for the public interest? Historically, the leadership for unorganized interests or for the public interest came from the Treasury Department and the Joint Committee staff. These two bodies were assumed to be operating in the public interest-they had an institutional interest in tax policy that operated as a counterweight to economic self-interest. Over the past decade, however, their influence has waned, particularly during periods when the offices were thought to be politicized. ${ }^{222}$ While both offices still provide neutral evaluations of policy, their voices no longer can be considered a strong offset to interest group politics. Much the same can be said about public-interest not-for-profit organizations interested in tax policy. While several of them provide good data and reports, ${ }^{223}$ they do not seem to have much effect in the political arena. Another notable decline in influence is that of labor unions who historically have represented diffuse

BUDGET (Dec. 13, 2010), http://crfb.org/document/creating-fiscal-turnaround-united-states; Solutions, PETER G. PETERSON FouND., http://pgpf.org/Special-Topics/HJ-Landing.aspx (last updated Nov. 9, 2010).

220. Shaviro, supra note 207 , at 102 .

221. Limited bipartisan efforts have occurred outside of Congress. For example, the National Commission on Fiscal Responsibility and Reform was chaired by former Republican Senator Alan Simpson and Erskine Bowles, who was Chief of Staff under President Clinton, and the Commission included members from both sides of the aisle. See Nat'l Comm'n on Fiscal Responsibility \& Reform, Commission Members, FISCALRESPONSIBILITY.GOV, http://www. fiscalcommission.gov/members (last visited Apr. 5, 2011). None of the Commission's proposals has been adopted, however.

222. See, e.g., Michael J. Graetz, Paint-by-Numbers Tax Lawmaking, 95 ColuM. L. REV. 609, 614-15 (1995).

223. See, e.g., TAX ANALYSTS, http://www.taxanalysts.com (last visited Feb. 7, 2011); TAX POL'Y CENTER, http://www.taxpolicycenter.org (last visited Feb. 7, 2011). 
groups, such as lower- and middle-income taxpayers. Today, labor unions have almost no voice in the tax policy debate. ${ }^{224}$

Finally, interest group politics can be offset by diffuse unorganized interests provided there is a strong consensus. Public opinion can act as a constraint on the legislative process. ${ }^{225}$ In this case, as explained further below, public opinion seems to be strongly in favor of no tax increases.

\section{The Poisonous Atmosphere with Respect to Taxes Prevents Increasing Taxes Directly}

Perhaps, no other factor better explains current tax politics (and thus, the unlikelihood of raising additional revenue) than the poisonous rhetoric with respect to taxes. It is widely agreed that public discourse about taxation has taken a nosedive, and it is impossible to discuss taxes publicly in any serious way. ${ }^{226}$ The anti-tax movement can be traced to Ronald Reagan, whose fight for smaller government inevitably brought with it a call for lower taxes. There are many forces that have carried this forward, from those who want to scrap the Internal Revenue Code, ${ }^{227}$ to the Contract with America's anti-tax rhetoric, ${ }^{228}$ to Steve Forbes's anti-tax presidential campaigns, ${ }^{229}$ to the campaign against the so-called "death tax,",230 to the jockeying among 2008 presidential candidates to make the most serious pledge not to raise taxes. ${ }^{231}$

This is largely attributable to two factors: the obsession with marginal tax rates and the impossibility of adopting any legislation that could be framed as "raising taxes." Congress and politicians go to extraordinary lengths to steer clear of taking any action that might be construed as raising taxes. This involves both labeling revenue-raising measures as something other than a tax, as well as trying to avoid raising the tax burden on anyone. An example of the

224. Michael J. Graetz \& Ian Shaptro, Death by a Thousand Cuts: The Fight over TAXING INHERITED WEALTH 107-08, 110-12 (2005).

225. See, e.g., William N. Eskridge, Jr., Politics Without Romance: Implications of Public Choice Theory for Statutory Interpretation, 74 VA. L. REV. 275, 287 (1988) ("[U]norganized interest may still have an impact if their preferences are strong and commonly held, for public opinion itself works as an important constraint on legislative action.").

226. Daniel Shaviro, The Long-Term U.S. Fiscal Gap: Is the Main Problem Generational Equity?, 77 GEO. WASH. L. REV. 1298, 1299 (2009) (lamenting the "debasement of public discourse and near impossibility of reasoned mainstream political debate about fiscal sustainability").

227. Alison Mitchell, Leaders of G.O.P. Seek To Overhaul Federal Tax Code, N.Y. TIMES, Sept. 28, 1997, at A1.

228. See Republican Contract with America, U.S. HOUSE OF REPRESENTATIVES, http://www.house.gov/house/Contract/CONTRACT.html (last visited Apr. 11, 2011).

229. Leslie Wayne, Flat Tax Goes from "Snake Oil" to G.O.P. Tonic, N.Y. Times, Nov. 14, 1999, at Al; Leslie Wayne, Forbes Emphasizes Position Against Abortion and Taxes, N.Y. TIMES, Jan. 23, 2000, at A16.

230. For the history of the term, see Graetz \& Shapiro, supra note 224, at 74-84.

231. Prepared Remarks of Senator Barack Obama (D-IL). Democratic Presidential Candidate, FED. NEWS SERVICE, Sept. 12, 2008 (reporting on a speech in which Obama made a "firm pledge" not to raise taxes on families making less than $\$ 250,000$ ); see Karen E. Crummey, McCain Talks Money, DENVER POST, July 8, 2008, at A-01. 
first is the debate over whether the penalty associated with the insurance mandate in the health-care legislation can be described as a tax. ${ }^{232}$ An example of the second tactic is the struggle over the 2001 and 2003 Bush tax cuts. Politicians are only too familiar with what happens if they can be tagged with raising taxes. The most salient example is President George H.W. Bush's "read my lips" pledge-it was widely assumed to be a major factor contributing to his reelection failure when his actions did not follow his lips. ${ }^{233}$

For the last decade, one political focus has been on marginal rather than effective tax rates. ${ }^{234}$ Both the President and Congress are terrified of the political repercussions of increasing the top marginal tax rate. One fallout from this obsession is that there can be no public discussion of raising revenue through a change in the rate brackets. Obviously, there are other ways to raise revenue-for example, by expanding the base-but the second factor precludes that as well. Anti-tax forces, particularly the Republican party, have relentlessly driven home the point that anything that might be described as a tax increase is bad. Thus, for example, failing to extend a temporary provision is labeled a tax increase. $^{235}$

This poisonous atmosphere is exacerbated by the public's lack of understanding about taxes. The public is remarkably uninformed about fiscal policy and taxation's role, and this ignorance prevents a public consensus that will act as a constraint on legislation as usual. While there are of course excellent and reliable sources of information about tax policy, their readership is essentially limited to the cognoscenti. The public, on the other hand, gets most of its information about tax policy from the general media, which usually limits its discussion of taxes to sound bites. Most of this information comes in the form of hostility to the concept of taxation. Politicians encourage this hostility to taxes, particularly the idea that our income tax system is truly awful. ${ }^{236}$ Although the shrillness of the rhetoric appears to be aimed at goading taxpayers into supporting change, the main effect appears to have been to poison public discussion about taxes.

Another problem is that nearly all of the public discussion focuses on the revenue side rather than the spending side. Most taxpayers do not seem to object to pronouncements about the need to end big government, but it is clear

232. See Robert Pear, Changing Stance, Administration Now Defends Insurance Mandate as a Tax, N.Y. TiMES, July 17,2010 , at Al4. 26,1993 , at A23.

233. See Charles Krauthammer, Op-Ed., Trapped by Campaign Rhetoric, WaSH. POST, Feb.

234. A focus on rates also brings a focus on redistribution with winners and losers. As Michael Graetz has pointed out, the discussion has turned to the distributional tables. See Graetz, supra note 222, at $610-12$.

235. See, e.g., Tax Increase Prevention and Reconciliation Act of 2005, Pub. L. No. 109-222, $\S 102,120$ Stat. 345,346 (2006) (to be codified at I.R.C. $\S 1$ ) (extending several temporary tax provisions).

236. See Marvin A. Chirelstein, Taxes and Public Understanding, 29 CONN. L. REV. 9 (1996) (noting public hostility to federal income tax, both toward paying taxes and toward the system itself). 
that they do not want to terminate any spending program of which they are beneficiaries. What motivates taxpayers has been remarkably constant over the last several decades: to pay as little tax as possible but to receive as many public benefits as possible. ${ }^{237}$ This is entirely consistent with public-choice theory since taxpayers are looking after their own self-interest.

\section{The Use of Low-Salience Taxes as a Second-Best Solution}

While no doubt economic considerations such as efficiency are important, in the real world, tax policy is often dictated by politics. This insight bolsters the normative argument for the government's taking advantage of cognitive error. While it would be counterproductive in many cases for the government to rely on low-salience tax provisions, there are situations where they may enable the government to achieve otherwise worthy goals. So long as the process is reasonably transparent and information with respect to the provision is readily available, there is no convincing argument that it would be wrong for the government to take error into account by effectively using politically pleasing taxes or provisions. The salience of the tax is exogenous to the provision itself in that it arises from the inability or unwillingness of a taxpayer to fully understand or react to a given provision. Thus, an attempt to minimize the perceived burden of a tax is not wrong per se. One reason that is so is that all of the information necessary to determine the actual burden is available.

The political-economy story of the current fiscal crisis and politics of taxation are a good illustration of when exploiting the cognitive bias in favor of low-salience taxes would be effective and appropriate. Congress needs revenue, but raising taxes-particularly through an increase in marginal rates-is politically difficult. Relying on low-salience tax provisions in a belief that they are more palatable than continued deficit spending is an acceptable choice for Congress to make.

Conclusion

Taxes and tax provisions-including the income tax-may have both economic and political salience. The former may affect economic decisionmaking and the later may affect the political response to legislation. This Article has shown that while relying on economic salience to increase efficiency with respect to the income tax is ambiguous, a democracy-enhancing case can be made for relying on political salience to increase political acceptance of low-salience taxes. The normative argument in favor of the government's exploitation of this cognitive bias does not suggest that this use is always appropriate or effective. In particular, we do not yet know enough about either the efficiency effects or the political response to low-salience tax

237. See Shaviro, supra note 207 , at 57 . 
provisions. Future research could help determine the extent to which economic responses to changes in income taxes are affected by the salience of the change. Research might also help to determine whether salience alone or in combination with other biases actually affects political responses to tax changes and whether legislators can rely on those responses. We also do not completely understand whether salience has a "shelf life" and whether, for example, taxpayers will debias and come to reject low-salience provisions. Much work is left to be done. But given the strong normative argument for the use of lowsalience provisions, further work on this research agenda is important. 


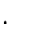

